Portland State University

PDXScholar

$12-11-1980$

\title{
The Ductuli Efferentes in Macaca mulatta: Electron Microscopic Evaluation of Changes After Vasectomy
}

Loyal Douglas Marsh

Portland State University

Follow this and additional works at: https://pdxscholar.library.pdx.edu/open_access_etds

Part of the Biology Commons, and the Developmental Biology Commons Let us know how access to this document benefits you.

\section{Recommended Citation}

Marsh, Loyal Douglas, "The Ductuli Efferentes in Macaca mulatta: Electron Microscopic Evaluation of Changes After Vasectomy" (1980). Dissertations and Theses. Paper 3060.

https://doi.org/10.15760/etd.3055

This Thesis is brought to you for free and open access. It has been accepted for inclusion in Dissertations and Theses by an authorized administrator of PDXScholar. Please contact us if we can make this document more accessible: pdxscholar@pdx.edu. 
AN ABSTRACT OF THE THESIS OF Loyal Douglas Marsh for the Master of Arts in Biology presented December 11, 1980.

Title: The Ductuli Efferentes in Macaca mulatta: Electron microscopic evaluation of changes after vasectomy.

APPROVED BY MEMBERS OF THE THESIS COMMITTEE:

David T. Clark, Chairman

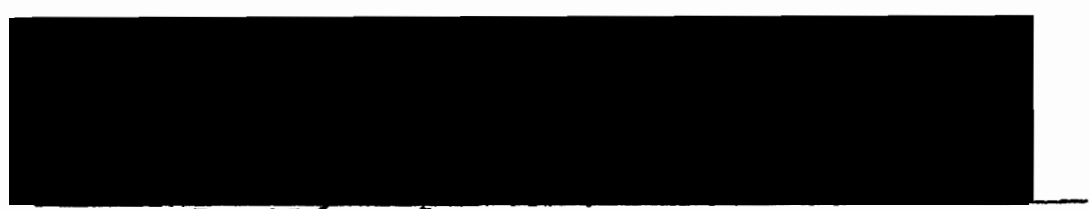

Nancy J. AZexander

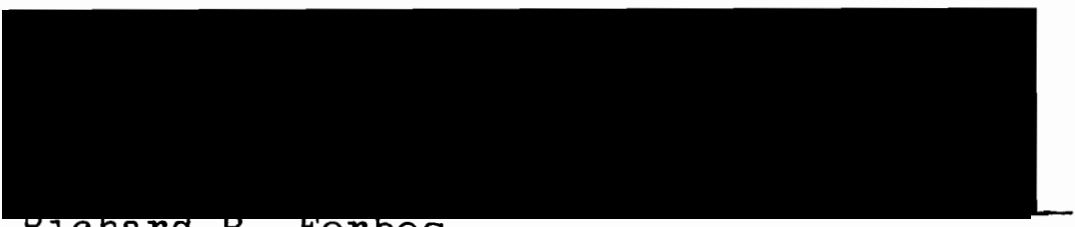

RIchard B. Forbes
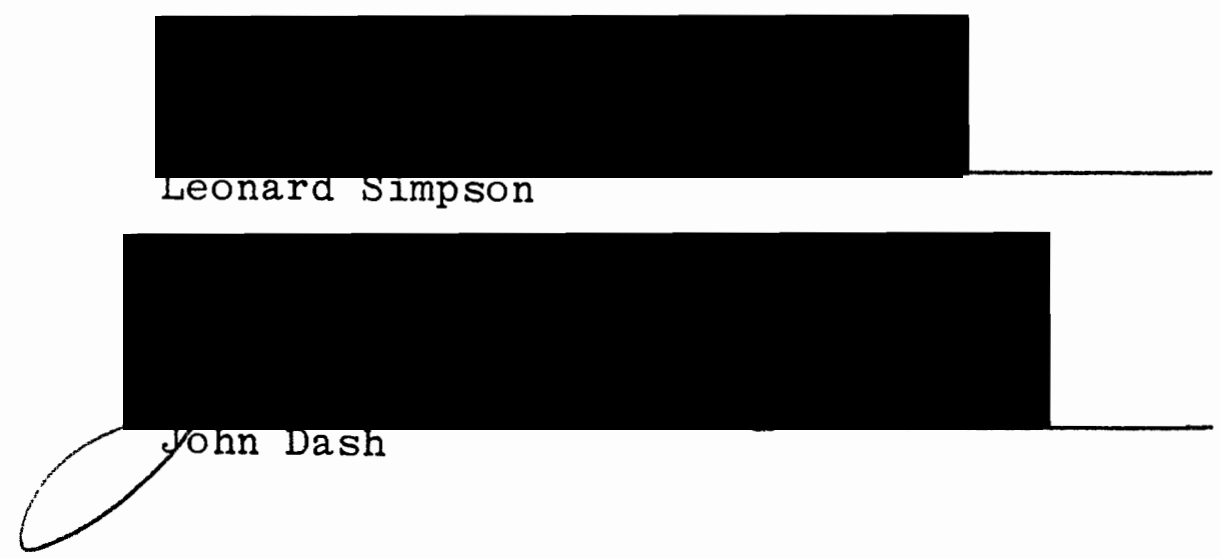

After vasectomy, the passage of sperm antigen through the epithelium of the efferent duct in the rhesus macaque 
probably results in immune complex deposition. Immune complexes can be visualized in the thickened basement by fluorescence microscopy. Subsequent electron microscopic evaluation, with the appearance of electron-dense deposits in the basement membrane of the efferent ducts, substantiates these findings. 
THE DUCTULI EFFERENTES IN Macaca mulatta:

ELECTRON MICROSCOPIC EVALUATION OF

CHANGES AFTER VASECTOMY

\author{
by \\ LOYAL DOUGLAS MARSH
}

A thesis submitted in partial fulfillment of the requirements for the degree of

\author{
MASTER OF ARTS \\ in \\ BIOLOGY
}

Portland State University 
TO THE OFFICE OF GRADUATE STUDIES AND RESEARCH:

The members of the Committee approve the thesis of

Loyal Douglas Marsh presented 11 December 1980.

Bavid T. Clark, Chairman

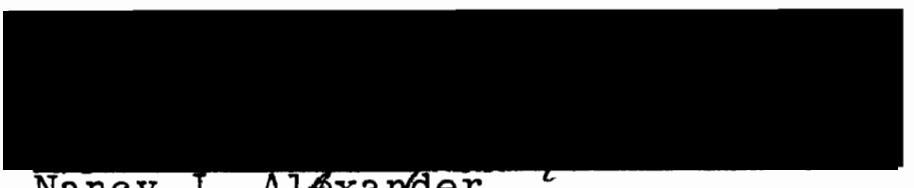

Nancy J. Alexayder

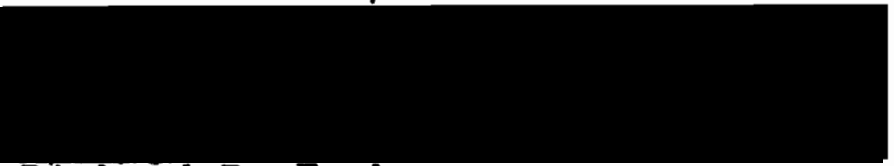

Richard B. Forbes

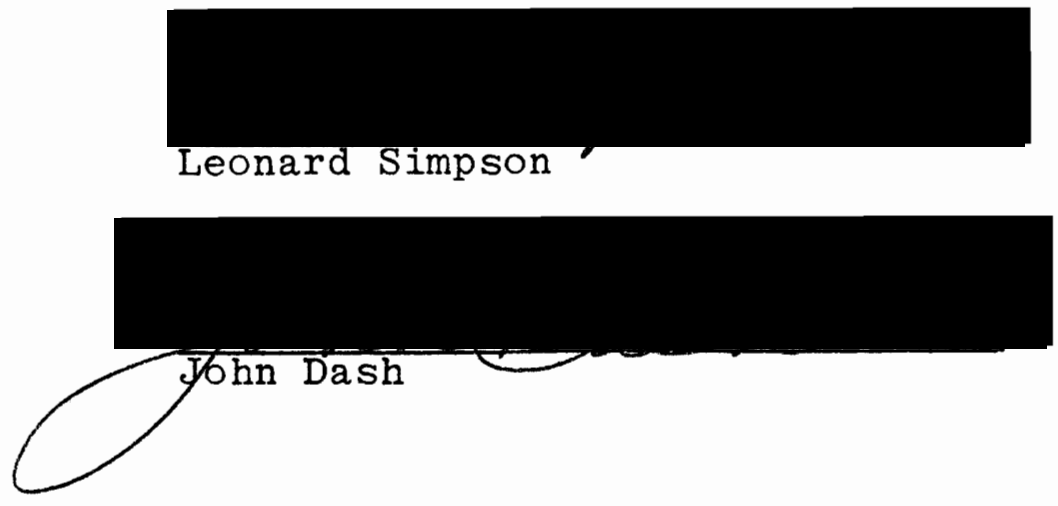

W. Herman Taylor, Head, Bigfogy Department 


\section{ACKNOWLEDGEMENTS}

The author wishes to express his sincere appreciation and indebtedness to $\mathrm{Dr}$. Nancy $\mathrm{J}$. Alexander of the Oregon Regional Primate Research Center. Without her expert guidance and valuable assistance this study would not have been possible.

The author also wishes to thank Dr. David T. Clark, Department of Biology, for his encouragement, and for his helpful suggestions in the preparation of this thesis. 
TABLE OF CONTENTS

PAGE

ACKNOWLEDGEMENTS ................... iii

LIST OF TABLES..................... vi

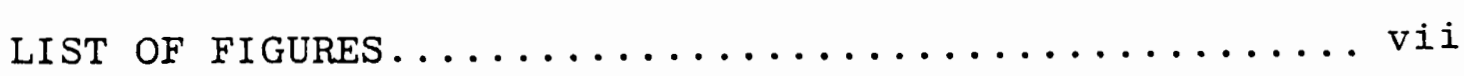

INTRODUCTION........................ 1

LITERATURE REVIEW..................... 3

Thickening of the Basement Membrane......... 6

Sperm in the Efferent Duct............. 6

Macrophages........................ 6

Plasma Celis...................... 8

Blood-Testis Barrier................ 8

Detection of Immune Complexes............ 10

MATERIALS AND METHODS.................... 11

Immunofluorescence Methods.............. 12

Electron Microscopic Methods.............. 13

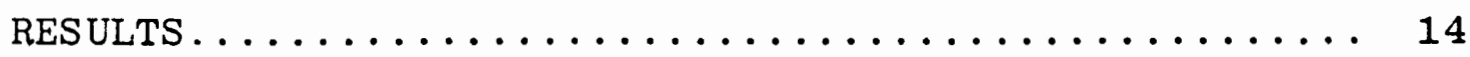

Nonciliated Cell................... 14

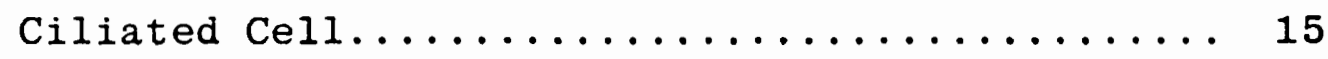

Epithelial Cell Junctions.............. 16

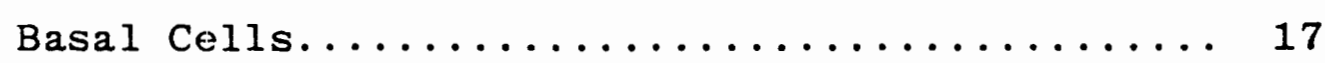

Basement Membrane.................. 17 
PAGE

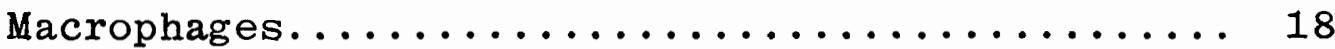

Postvasectomy Changes................... 18

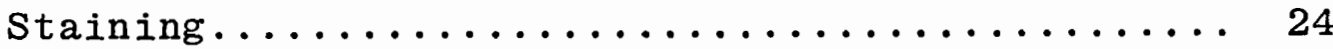

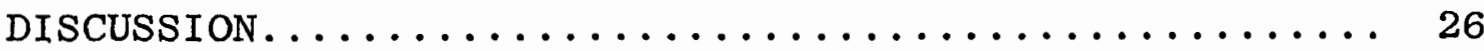

Thickening of the Basement Membrane After

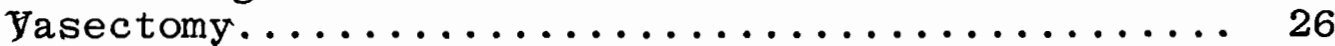

Decrease in Ciliated Cells................ 28

Infiltration by Plasma Cells and Macrophages.... 28

Immune Complex Formation.................. 29

Localization of Immune Complexes in the

Basement Membrane..................... 31

Consequences of Immune Complex Deposition....... 32

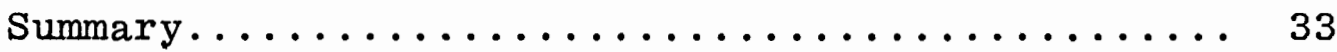

LITERATURE CITED. ......................... 53 


\section{LIST OF TABLES}

TABLE

PAGE

I Width of the Efferent Duct Basement Membrane

As a Function of Time After Vasectomy..... 20

II Area of Immune Complex Deposits as a

Function of Time After Vasectomy........ 23 


\section{LIST OF FIGURES}

1 The nonciliated cells of the nonvasectomized monkey contain numerous granules (g) in the apical cytoplasm.... 35

2 Ciliary rootlets (cr) extend deep into the cytoplasm of the ciliated cell and come into contact with mitochondria (m)..... 35

3 Basal cells (bc) are sometimes seen in basal regions of the efferent duct epithelium.. 37

4 Both the ciliated cells (Cc) and non-ciliated cells (NC) become shorter after

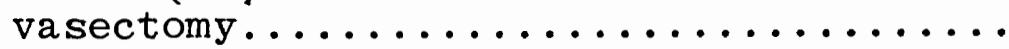

The number of sperm in the lumen increase after vasectomy................ 39

6 Sperm remnants ( $\mathrm{Sr}$ ) are seen within luminal macrophages of the efferent duct....... 39

7 Within 1 year after vasectomy the basement membrane thickens by folding of many

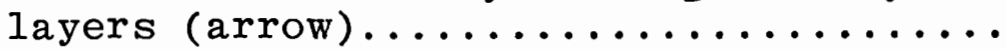

8 A homogeneous sheet of basement membrane (bm), sometimes up to $3 \mu \mathrm{m}$ wide, is seen in monkeys vasectomized at least

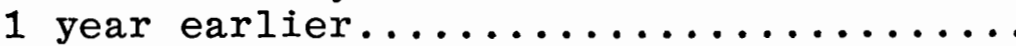

9 Invaginations (i) of the basement membrane $(\mathrm{bm})$ into the epithelium (E) are seen....

10 The basement membrane is made up of a fibrillar component in an amorphous

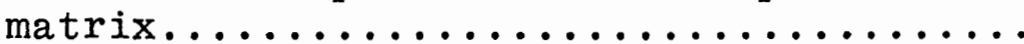

11 After vasectomy large numbers of leukocytes (le) are seen directly beneath the

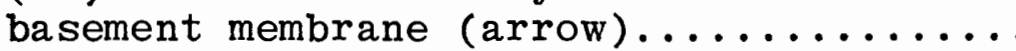


12 The basement membrane (arrow) surrounding the efferent duct epithelium (E) fluoresces when tested with fluorescein-conjugated antibody; this indicates the presence of immune

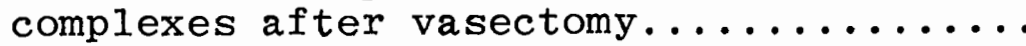

13 Electron-dense immune complexes (arrow) are seen in the basement membrane (bm)

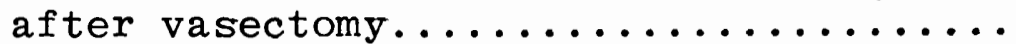

14 The immune complexes (arrow) appear quite different from the bundles of collagen fibers (cf) adjacent to and sometimes coursing through the basement membrane... 47

15 The immune complexes (arrow) vary in density, often appearing very dark............................

16 Plasma cells (Pc) with a markedly developed thumbprint pattern of endoplasmic reticulum are seen directly beneath the basement membrane (bm) after

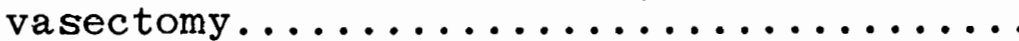

17 In 2 of 12 monkeys with immune complex deposits (arrow), plasma cells (Pc)

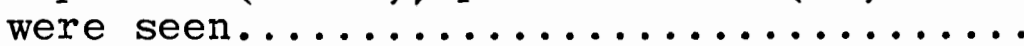

18 Staining sections with uranyl acetate and lead citrate makes it hard to discern the immune complexes (arrow) from the surrounding basement membrane $(\mathrm{bm}) \ldots . .$. 


\section{INTRODUCTION}

Vasectomy confines sperm to the epididymis and proximal vas deferens by interrupting the reproductive duct at the ductus deferens. The imprisoned spermatozoa are engulfed by macrophages, or degenerate; and they probably release numerous antigens. These antigens are believed to leak out of the reproductive tract and into the circulation where they elicit the production of autoantibodies. Furthermore, the number of macrophages increases in the ducts, and possibly contributes to the release of sperm antigens, or active transport of antigens into the circulation. In human beings and primates, several different antisperm antibodies develop within two weeks after vasectomy (Alexander 1977).

Studies were initiated to elucidate the immune response after vasectomy. Frozen sections of testis and epididymis were evaluated through the use of fluoresceinconjugated antibodies and fluorescence microscopy. Positive immunofluorescence staining for complement showed deposits of immune complexes in the region surrounding the efferent ducts (Alexander and Tung 1979b). A thorough study of the efferent ducts was conducted with the electron microscope in order to verify that the basement membranes surrounding the efferent ducts are indeed a site of immune complex localiza- 
tion in the rhesus macaque. 


\section{LITERATURE REVIEW}

Vasectomy impedes the flow of sperm, and therefore may be involved in changes in both the testis and excurrent ducts. I will review pertinent literature on the normal rhesus testis and the literature describing changes that occur after vasectomy.

The normal testis is composed of seminiferous tubules and interstitial cells. AII stages of spermatogenesis are present in the seminiferous tubules, and the interstitial cells secrete androgens. At the upper pole of the rhesus testis, 12 tubules called ductuli efferentes, or efferent ducts, exit from the testis. These ducts (275 to $350 \mu \mathrm{m}$ in diameter) arise from the rete testis and serve as conduits for the spermatozoa as they leave the seminiferous tubules of the testis and are propelled into the ductus epididymidis and vas deferens (Ramos and Dym 1977).

The efferent ducts possess a tall columnar epithelium (25 $\mu \mathrm{m}$ high) consisting of ciliated and nonciliated cells. The nuclei of the ciliated and nonciliated cells are different from each other in structure and location. With a light microscope the cytoplasm of nonciliated cells appears more deeply stained than that of ciliated cells. The nuclei of nonciliated cells, located predominately in the basal part of the cytoplasm, are irregularly shaped owing to 
numerous nuclear envelope indentations. The spherical nuclei of the ciliated cells occur in the middle or apical regions and do not display deep nuclear membrane indentations.

The nonciliated cells, which contain many vesicles and vacuoles, are probably important absorptive cells in the region. The ability of vesicles and vacuoles in the epithelium of efferent ducts to participate in the absorption of substances in solution in the luminal fluid has been demonstrated (Yokoyama and Chang 1971). Since sperm are always moved in a fluid medium, the efferent ducts probably add some secretion products to the seminal plasma (Alexander 1972).

The millions of spermatozoa produced daily pass rapidly through the efferent ducts aided by the action of the ciliated cells lining the efferent ducts. In sections, the ducts usually appear devoid of spermatozoa since the cilia rapidly propel the sperm along when there is no blockage of the ducts.

Basal cells are occasionally observed in the epithelium of the efferent ducts of monkeys; this fact means that the epithelium is pseudostratified instead of simple columnar. These basal cells have the appearance of small, unstimulated lymphocytes, but these cells do not seem peripatetic since none have been observed crossing the basement membrane nor migrating into the lumen (Fawcett 1979). The nucleus of the lymphocyte-like cell is round or ovoid with or without indentations, and very little heterochromatin is present. The 
cytoplasm contains few distinguishing features revealing simply some endoplasmic reticulum, a small Golgi apparatus and some mitochondria (Ramos and Dym 1977).

Cells of the immune system other than lymphocytes are occasionally observed. Macrophages are sometimes seen in the lumen and surrounding connective tissue, as are periductular lymphocytes.

The epithelium of the efferent ducts rests upon a distinct basement membrane, and beneath this are scanty amounts of connective tissue, fibroblasts, some smooth muscle cells, and periductular capillaries. In situ, these components are surrounded by an abundance of adipose tissue (Ladman 1958).

Normally, the lamina propria consists of an $800-\AA-$ thick basement membrane, applied to the basal surface of the tubules of the testis. Biochemical analysis of the basement membrane shows that this structure contains mucopolysaccharides and proteins similar to collagen (Nadol and Gibbons 1970).

The outer aspect of the basement membrane faces a number of layers (usually not more than six) of alternating fibroblast-like cells (contractile) and intercellular spaces mostly occupied by collagen fibers (Bustos-Obregon 1976).

Under normal conditions the basal lamina in the human testis forms a continuous, homogeneous matrix with some infolding or protrusions toward the epithelim (Chakraborty et a2. 1976). 
Thickening of the Basement Membrane

According to Chakraborty (1976), the basement membrane may thicken or become multilayered in appearance after vasectomy. The reasons for this thickening are not known, and little is known about how the basement membrane undergoes this dramatic increase in width. Perhaps even more confusing are the large number of convoluted layers and irregularities that develop.

Sperm in the Efferent Duct

Since their exit has been obstructed, the number of sperm in sections of the efferent duct increases after vasectomy. With this increase is a concurrent increase in the number of macrophages in the lumen. Sperm remnants are seen within the luminal macrophages. Occasionally, macrophages located outside the ducts contain recognizable sperm remnants; this signifies that there is migration of macrophages in and out of the ducts (Tung and Alexander 1980).

Macrophages

The mononuclear phagocyte concept, $i . e .$, that free macrophages are descendants of blood monocytes (van Furth et al. 1972), appears to be valid also for the internal male genital system. Precursors of macrophages enter the seminiferous tubules even under normal conditions (Holstein 1978). These cells resemble blood monocytes. Transitional forms of blood monocytes and mature macrophages have been seen; these 
eventually contain spermatozoa.

The morphological picture of macrophages differs in various parts of the excretory ducts. The largest macrophages have diameters up to $60 \mu \mathrm{m}$, often contain two to four nuclear lobes and are found in the epididymis.

The macrophages of the efferent ducts have ruffled plasma membranes, and in each the cytoplasm contains a large Golgi apparatus, many phagocytic and pinocytic vesicles, and numerous lysosomes. They have an oval nucleus with little or no heterochromatin; this fact, along with the presence of engulfed sperm, indicates that the cell is actively engaged in phagocytosis.

Macrophages have the capacity to bind to antigen and antigen-antibody complexes. It is thought that this capacity, and subsequent degradation of antigens, are important in the induction phase of the immune response (Marchalonis 1978). Furthermore, membranes of cells of the macrophage series have the capacity to bind the Fc portion of antibodies of certain immune complexes. Under appropriate in vitro conditions, binding of small amounts of antigen-antibody complexes may activate phagocytosis. Membrane receptor sites for immunoglobulins of the class IgG have been described on macrophages; in addition, binding sites for activated C3 have been noted (Wing and Remington 1978). Theofilopoulos (1980) states that after phagocytosis of immune complexes by macrophages, Fc subfragments are released which, 
via Fc-receptor-bearing helper T cells, stimulate $B$ cells to proliferate and differentiate to plasma cells. Thus the presence of large numbers of macrophages within the lumina of the efferent ducts after vasectomy is evidence of a complex immune response.

\section{Plasma Celis}

Plasma cells are often seen in the interstitial area exterior to the basement membranes of the efferent ducts after vasectomy. These cells are easily distinguished by transmission electron microscopy because of their markedly developed granular endoplasmic reticulum (Douglas 1978). Such organized endoplasmic reticulum is indicative of a secretory function and, in fact immunoglobulin synthesis may constitute up to $43 \%$ of the protein synthesis in the plasma cell.

\section{Blood-Testis Barrier}

The blood-testis barrier is formed within the seminiferous tubule as tight Sertoli-to-Sertoli cell junctions. Each tight junction, consisting of a large number of surface cellular elements in a parallel array, gives the appearance of regions of membrane fusion between Sertoli cells. Both the abundance of these regions and their arrangement distinguish the Sertoli cell tight junctions from similar junctions in other tissues. One of the primary functions of the blood-testis barrier appears to be an immunologic one, 
namely to isolate sperm-specific autoantigens as well as to protect against sperm-specific antibodies (Neaves 1977).

There is speculation that the blood-testis barrier may change after vasectomy. Perhaps pinpoint breakdowns in this barrier occur with passage of antigen, and this may account for the triggering of the immune system.

The development of a sperm-specific immune response after vasectomy requires that sperm antigens, previously separated from immunocompetent cells possibly by the bloodtestis barrier, become available to the lymphoid system. Considering the highly diffusible antigens that can be released from the acrosome of degenerating sperm, autosensitization after vasectomy probably requires passage only of these antigens, not of whole sperm, through the duct walls (Johnson 1970).

However, the narrowest and probably the least effective junctions are those between the cells of the efferent ducts rather than the Sertoli cells (Fawcett 1979). An indication of their potential leakiness is the fact that in rats, lanthanum, used as an electron opaque probe, occasionally penetrates throughout the intercellular space and reaches the lumen of the efferent duct (Suzuki and Nagano 1978). Immunologic isolation of sperm antigen is apparently less effective in the excurrent ducts than in the seminiferous tubule, a phenomenon that explains the greater vulnerability of antigen in the former (Neaves 1973). 
Detection of Immune Complexes

There are two main methods of localizing tissueassociated immune complexes. One is the fluorescent antibody technique, in which antibodies against a particular constituent are labeled with fluorescein isothiocyanate and incubated with a frozen tissue section. After the unbound proteins have been washed from the tissue, the sections are examined under ultraviolet light in a microscope and a bright fluorescence is seen where the corresponding labeled antigen is located (Coons and Kaplan 1950).

An alternative way to detect tissue-localized immune complexes is electron microscopy. The presence of immune complexes can be inferred from the observation of electrondense deposits within the amorphous basement membrane. Such deposits have been seen in glomerular basement membranes as well as in skin (Nydegger 1979). 


\section{MATERIALS AND METHODS}

Tissues were taken from rhesus macaques (Macaca mulatta) housed and maintained at the Oregon Regional Primate Center (ORPRC). The animals used in this study were adult males that had been vasectomized for periods of 1 to 12 years and intact controls that were equivalent in age to the animals in the vasectomy group. There were 11 male control and 36 vasectomized monkeys. Some of the monkeys were acquired from India as young adults (6-8 years of age). The age of these animals was an estimate; however, estimation of age of young adults on the basis of dentition is considered accurate within one year. All the animals had been in captivity and fed normal monkey chow for ten years or more at the ORPRC.

All monkeys were weighed every 30 days and tested for tuberculosis every 60 days. No differences in the body weights were observed between the groups.

The animals were fed twice daily a diet of Purina monkey chow (15\% protein) devoid of cholesterol, that contained about $6 \%$ fat derived primarily from plant sources. The animals were given fruit supplementation (oranges, apples, and bananas) three times a week.

During the course of study of these animals at the ORPRC, a considerable amount of clinicopathological data 
acquired. Measurements were made on serum for concentration of electrolytes, calcium, phosphorus, triglycerides, total cholesterol, urea nitrogen, creatinine, albumin, and globuIin.

Sperm-agglutination, sperm-immobilization, and immunofluorescence tests were used in assessment of circulating antibody titers against sperm in all the animals. These determinations were done twice a year for the last seven years on the vasectomized group, and for the last four years on the control group.

Necropsies were done at the ORPRC. The animal was anesthetized with ketamine and exsanguinated from the inferior vena cava. Tissues from the reproductive tract were taken for immunofluorescence and electron microscopic studies. The carotid arteries, the thoracic aortas, the abdominal aortas, and the iliac arteries were also taken for use in another study by Clarkson and Alexander (1980).

\section{Immunofluorescence Methods}

For the fluorescein-labeled antibody studies, efferent duct tissues from nonvasectomized and vasectomized monkeys were excised at necropsy and placed in liquid nitrogen. Sections were cut $4 \mu \mathrm{m}$ thick with a microtome-cryostat, fixed for 20 minutes in $95 \%$ ethanol, rinsed in phosphatebuffered saline, and stained for 45 minutes with goat antimonkey $\mathrm{C}^{\prime} 3$ and rabbit antimonkey IgG and IgA conjugated 
with fluorescein isothiocyanate. Sections were then rinsed in phospate-buffered saline, dried, and mounted in glycerine (Alexander 1972). Sections were viewed with a Zeiss epifluorescence microscope.

Electron Microscopic Methods

Efferent duct tissues were taken by biopsy and at necropsy from nonvasectomized monkeys and monkeys vasectomized 1 to 12 years earlier. The tissues were fixed for 2 hours in $0.75 \%$ glutaraldehyde, $4 \%$ formalin, $3.5 \%$ sucrose,

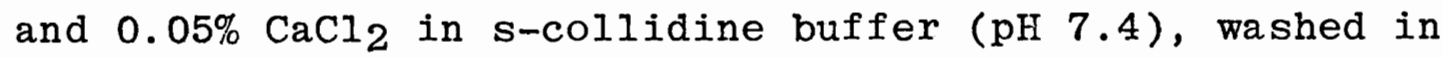
buffer, postfixed in $1 \%$ osmium tetroxide, dehydrated in alcohol, and embedded in Araldite. Thick sections were stained with $1 \%$ toluidine blue in $1 \%$ borax. Thin sections showing silver to pale gold interference colors were cut with glass knives on a Porter-Blum MT2 Ultramicrotome, stained with potassium permanganate and lead citrate, or uranyl acetate and lead citrate, and viewed with a Philips 300 electron microscope. 


\section{RESULTS}

I describe here the composite picture of the efferent ducts of vasectomized and nonvasectomized rhesus macaques from 47 animals. The efferent duct is composed primarily of a single layer of ciliated and nonciliated cells resting on a thin basement membrane.

\section{Nonciliated Cell}

A striking feature of nonciliated cells of the efferent duct was the abundance of large membrane-bound vesicles. These ranged in diameter from 1 to $7 \mu \mathrm{m}$ and were present in all parts of the cytoplasm, even the basal regions (Fig. 1). The density of the vesicular contents varied somewhat among vesicles within a given cell, but a greater variation was seen from one region of the epithelium to another; some electron-lucent vesicles contained only a few wisps of material and some structures were extremely electron-dense. The number, size, and density of the vesicles differed in adjacent cells. The membranes limiting some of the vesicles occasionally were broken and much of their contents was located in the surrounding cytoplasm.

The apical portion of the cell was covered with microvilli of uniform height. Between the microvilli, shallow invaginations of canaliculi extended downward into the cyto- 
plasm. The canaliculi ended in terminal pockets, and at times appeared continuous with vesicles at these ends. Mitochondria of various sizes were scattered throughout the cytoplasm. They were far less numerous and generally smaller than those found in ciliated cells. Endoplasmic reticulum was not abundant, but numerous free ribosomes and some polysomes were present. Golgi elements were well developed. A few membrane-bound dense bodies, presumed to be lysosomes, were also present in the cytoplasm. The cytoplasmic matrix of the nonciliated cells was denser than that of the ciliated cells.

The nuclei of nonciliated cells were irregular and tended to lie in the basal portions of cells. The nuclei were relatively small and, in contrast to the ciliated cells which had smooth spherical contours, they displayed numerous deep nuclear envelope infoldings. Electron-dense heterochromatin predominated in the karyoplasm, especially along the inner aspect of the nuclear envelope.

\section{Ciliated Cell}

Viewed with the electron microscope, the apical and supranuclear regions of the ciliated cell cytoplasm possessed accumulations of electron dense bodies of different sizes. Some of these structures were homogeneous, and others contained darker particles.

The apical surfaces of the cells were provided with 
many cilia and microvilli. The cilia were 0.2 to $0.3 \mu \mathrm{m}$ in diameter and showed the $9+2$ bundles of microtubules. Each cilium terminated in a basal body just below the cell surface. Some of the basal bodies had extensions or spurs protruding from their lateral sides. Diverging striated rootlets arose from the ciliary bodies, extended into the supranuclear cytoplasm, and came into close assoication with the nucleus, mitochondria, and microtubules (Fig. 2).

Throughout its cytoplasm each ciliated cell contained rod-shaped mitochondria with typical transverse cristae and dense matrices. The mitochondria tended to be concentrated in the supranuclear regions of the cells. Numerous microfilaments were also present in the cytoplasm. Endoplasmic reticulum was not very prevalent, although some was seen in the supranuclear zones. The Golgi apparatus was usually located in the apical cytoplasm.

Ciliated cell nuclei contained mostly euchromatin and prominent nucleoli.

Epithelial Cell Junctions

Lateral plasma membranes between adjoining epithelial cells had numerous infoldings and interdigitations, especially in the middle third and basal regions. Occluding junctions were present near the luminal surface, and desmosomes occurred on the boundaries between adjacent epithelial cells. 
Junctional specializations were present between nonciliated and ciliated cells next to the lumen of the efferent ducts. There was a narrow tight junction region next to the lumen in which the membranes of the two cells approached one another closely and sometimes fused for a distance of $1.0 \mu \mathrm{m}$.

$\underline{\text { Basal Cel1s }}$

Basal cells, or lymphocytes, were present in small numbers in the epithelium of the efferent ducys. They possessed irregularly shaped nuclei with abundant electrondense heterochromatin and a thin rim of pale cytoplasm (Fig. 3). They frequently had pseudopods, but were only seen in the basal regions of the epithelium. No specialized junctions or interdigitations with plasma membranes of neighboring cells were noted.

Basement Membrane

The epithelium of the efferent ducts rested on a thin basement membrane ( $800 \AA$ thick) that consisted of a homogeneous component of moderate electron density. Aggregates of collagen fibers and other fibrillar structures were usually seen in close association with the basement membrane. Beneath the membrane, there was connective tissue with fibroblasts and abundant collagen fibers. On the external aspect of the fibroblasts there was sometimes a layer of smooth muscle. Numerous blood vessels and some macro- 
phages were also located within the interstitial connective tissue.

\section{Macrophages}

Macrophages were a constant component in the efferent ducts. They occurred in the peritubular connective tissue, in the luminal contents and more rarely within the epithelium proper of specimens in this study. Macrophages in the lumen had the ultrastructural features of free macrophages. They had many surface projections, and their cytoplasm contained numerous pinocytic vesicles, some vacuoles, and numerous lysosomes. The nuclei were oval or kidney-shaped, had a thin band of chromatin around the nuclear membranes, and were positioned eccentrically.

\section{Postvasectomy Changes}

Observations on efferent duct tissues after vasectomy showed a decrease in the number of cells with cilia, and microvilli were primarily seen lining the lumen of the ducts. Only 2 of the 36 vasectomized monkeys showed no difference in the epithelial cells after the procedure.

The efferent ducts in monkeys vasectomized 1 year earlier had a two- to fourfold increase in diameter, most likely as a result of being packed with spermatozoa and fluid. Both the ciliated and nonciliated cells became shorter (14 $\mu \mathrm{m}$ high) as the ducts stretched.

After vasectomy most nonciliated cells (in 34 of $3 \dot{6}$ 
vasectomized monkeys) lost their dense apical membranebound granules (Fig. 4). The membranes limiting some of the vesicles were occasionally broken, but this disruption may have been an artifact of specimen preparation. Some nonciliated cells retained empty vacuoles after vasectomy, and the differences in size suggested that fusion of the vesicles had taken place.

The cytoplasm of the ciliated cells remained virtually the same as in the nonvasectomized animals; however, the few electron-dense bodies in the apical regions disappeared.

After vasectomy, the number of sperm in the lumen of the efferent ducts increased (Fig. 5). Numerous macrophages were present and could be seen engulfing and digesting spermatozoa (Fig. 6). The epithelial cells themselves did not contain recognizable sperm remnants before or after vasectomy.

The basement membrane was strikingly thicker after vasectomy. Thickening in animals vasectomized less than 1 year earlier occurred as a series of layers (Fig. 7). One year after vasectomy, efferent duct tissues from some monkeys had basement membranes that were approximately $1 \mu \mathrm{m}$ wide (Table I). Animals that had been vasectomized more than 6 years earlier had basement membranes that were sometimes up to $3 \mu \mathrm{m}$ wide (Fig. 8).

Numerous 1 - to 2- $\mu$ m-deep protrusions of the basement 


\section{TABLE I}

WIDTH OF THE EFFERENT DUCT BASEMENT MEMBRANE AS A FUNCTION OF TIME AFTER VASECTOMY

Width of Basement Membrane $(\mu)$

\begin{tabular}{lccc}
$\begin{array}{c}\text { Animal } \\
\text { Number }\end{array}$ & Since Vasectomy & Average & Greatest \\
\hline 3150 & 11 & 2.7 & 3.0 \\
1501 & 8 & $4.5 *$ & $5.0 *$ \\
4497 & 7 & $3.7 *$ & $4.0 *$ \\
1061 & 6 & 2.3 & 3.0 \\
7946 & 5 & 2.3 & 3.2 \\
7940 & 4 & 1.5 & 1.8 \\
7937 & 4 & 1.3 & 1.5 \\
7948 & 3 & $2.1 *$ & $2.3 *$ \\
7142 & 3 & 1.0 & 1.0 \\
7158 & 1 & 0.9 & 1.0 \\
1561 & nonvasectomized & 0.08 & 0.1
\end{tabular}

*Denotes tangential section 
membrane towards the epithelium were seen. Some portions of the protrusions in a different plane of sectioning appeared to be cut off from the original stalk (Fig. 9). Occasionally these cut off portions, which looked like inclusion bodies, were found as far as $2 \mu \mathrm{m}$ from the basement membrane.

At certain points some parts of the protrusions that were already greatly advanced into the epithelium exhibited thickening in areas away from the basement membrane; this thickening left the basal portion narrow. The matrix of the wider areas of the basement membrane contained large amounts of homogeneous material with fine filamentous elements and some granular and membranous components.

High resolution microscopy of the basement membrane revealed the presence of another fibrillar component, microfilaments (Fig. 10). These varied in diameter from 50 to $100 \AA$ and occurred throughout the membrane.

Many times a great number of leukocytes were seen beneath the basement membrane after vasectomy (Fig. 11). Frozen sections of efferent ducts were tested with fluorescein-conjugated antibody; basement membranes surrounding the ducts from vasectomized monkeys fluoresced green-yellow (Fig. 12).

Furthermore, with the electron microscope, electrondense deposits were found in basement membranes that had thickened to at least $1 \mu \mathrm{m}$ (Fig. 13). The deposits appeared 
granular, sometimes differed in density, were scattered throughout the homogeneous matrix, and many times occurred in the invaginations of the membrane into the epithelium. The electron-dense deposits were distinctly different from the collagen adjacent to and sometimes coursing throughout the basement membrane (Fig. 14). The deposits were much larger, and had irregular shapes, unlike the bundles of long collagen fibers, which in cross-section resembled piles of logs. The deposits usually appeared darker than the collagen (Fig. 15).

None of the nonvasectomized monkeys had deposits in their membranes, but 12 of 36 vasectomized animals did have electron-dense deposits.

The deposits varied in size--some of the larger ones measured $2 \mu \mathrm{m}$ by $0.5 \mu \mathrm{m}$ (Table II). Cross-sectional areas of deposits ranged from $0.01 \mu \mathrm{m}^{2}$ in a monkey vasectomized 3 years earlier, to $1.34 \mu^{2}$ in an animal vasectomized 7 years earlier. The largest deposits in the basement membrane occurred in animals vasectomized at least 7 years earlier. Monkeys vasectomized 4 years earlier had a slightly smaller average cross-sectional area, and animals vasectomized 3 years earlier had deposits of the smallest size. Of course, the size may have varied according to the angle at which the sections had been cut.

The animals that had been vasectomized the greatest number of years ago had the greatest number of deposits; 
TABLE II

AREA OF IMMUNE COMPLEX DEPOSITS AS A FUNCTION OF TIME AFTER VASECTOMY

Area of Deposits $\left(\mu^{2}\right)$

\begin{tabular}{cccc}
$\begin{array}{c}\text { Animal } \\
\text { Number }\end{array}$ & Since Yasectomy & Average & Greatest \\
\hline 1062 & 12 & 0.37 & 1.25 \\
3150 & 11 & 0.30 & 0.97 \\
4497 & 7 & 0.40 & 1.34 \\
1061 & 6 & 0.16 & 0.20 \\
7940 & 4 & 0.25 & 0.80 \\
7937 & 4 & 0.17 & 0.70 \\
7142 & 3 & 0.01 & 0.03
\end{tabular}


the trend was for the number of deposits to increase as the time since vasectomy increased.

Numerous plasma cells in the connective tissue surrounding the efferent ducts were observed in four monkeys that had been vasectomized at least four years earlier (Fig. 16). No plasma cells were seen in nonvasectomized animals.

In 2 of the 12 monkeys with deposits, there were many plasma cells directly beneath the basement membrane. Cisternae of the endoplasmic reticulum in the plasma cells were greatly distended by the accumulation of the cell product; they formed a labyrinth of spaces, separated by narrow septa of cytoplasm containing the mitochondria and free ribosomes (Fig. 17).

The type of antibody the plasma cells were producing could not be determined since immunofluorescence tests on these sections of efferent duct showed no evidence of antibody. Different areas were taken for light microscopy than for electron microscopy, thus plasma cells and deposits were found in some sections where no fluorescence occurred.

\section{$\underline{\text { Staining }}$}

Early in this study, sections of efferent duct were stained with uranyl acetate and lead citrate. The resulting poor contrast made it difficult to tell if inclusions of the basement membrane were part of the membrane itself or actually separate entities (Fig. 18). Sections were then 
stained with potassium permanganate, a phospholipidprotein-complex stain that increased contrast immensely. By this method, electron-dense deposits showed vividly in the basement membrane. 


\section{DISCUSSION}

My electron microscopic data on the efferent ducts of nonvasectomized and vasectomized rhesus macaques support the results of Alexander (1972) and Ramos and Dym (1977). Earlier studies on the rabbit showed the presence of deposits in the basement membrane of the seminiferous tubules after vasectomy (Bigazzi et al.1976). The results of my research demonstrate a new finding, namely the presence of electrondense deposits in the thickened basement membranes surrounding tine efferent ducts of vasectomized monkeys. This finding will probably be demonstrated in man when more data become available.

Thickening of the Basement Membrane After Vasectomy

There is little literature on the thickening of the basement membrane in the efferent duct, however a layered thickening of the basal lamina inthe capillary system takes place after vascular injury.

When there is damage to the vascular system, as in diabetes mellitus or aging, there is a thickening of the basal lamina. Thickening in the peripheral capillaries of man is not homogeneous; instead, the excess material surrounding the capillaries is composed of discrete, concentric layers, each layer resembling a single, normal layer of 
basal lamina (Vracko 1972).

After vasectomy the efferent ducts become distended by the accumulation of sperm and fluid and the basement membrane thickens considerably. Thickening first occurs, as in the case of capillary damage, by the formation of layer upon layer of basal lamina as in Figure 7. Since the basement membrane is produced by the epithelium, this layering must occur from the inside, adjacent to the epithelium. One year after vasectomy, the multilaminated basement membrane has transformed to a smooth, homogeneous matrix of moderate electron density and a width of at least $1 \mu \mathrm{m}$.

It is possible that the machinery of the epithelial cells--which ordinarily makes only a single, "normal" layer of basement membrane--sometimes is stimulated to produce additional layers. Injury such as vasectomy causes the efferent duct epithelium to synthesize more materials and deliver them to the basement membrane, which in turn folds and forms a multilaminated structure. The numerous layers eventually resemble a smooth sheet of membrane.

In my studies, some basement membranes measured as wide as $5 \mu \mathrm{m}$ when the tubules were cut tangentially, but when I deleted values for tangential sections I found that the widths of the basement membranes increased slightly with time since vasectomy.

Within this wide homogeneous basement membrane are 
electron-dense deposits. These deposits correspond to the immune complexes detected in the basement membrane with fluorescein-conjugated antibody.

Decrease in Ciliated Cells

The decrease in the number of ciliated cells after vasectomy may be due to a loss of cilia, thus exposing the underlying microvilli; it does not seem likely that whole ciliated cells would vanish or that nonciliated cells would increase in number.

\section{Infiltration by Plasma Cells and Macrophages}

The increase in the number of plasma cells beneath the basement membrane after vasectomy suggests that sperm antigens elicit the production of antisperm antibody (Fig. 17). The nuclei of these plasma cells have regularly spaced, large blocks of chromatin around the periphery and a large mass in the center. Such a coarse pattern is unexpected in a cell actively synthesizing antibody protein (Fawcett 1966). It is conceivable, however, that in a cell so highly specialized in its function only a small proportion of the DNA would be needed in an active form to direct the narrow range of synthetic activities carried out in its cytoplasm--namely, the production of antisperm antibody.

Although macrophages were not counted, it was evident that more macrophages were present in vasectomized monkeys. This supports reports in the literature which maintain that 
long-term vasectomy in rhesus macaques eventually leads to an increase in sperm digestion by intraluminal macrophages in the efferent ducts (Alexander 1972). In the rat, not only do macrophages help dispose of sperm after the epididymis has been obstructed, but also nonciliated cells in the epithelial lining of the efferent ducts begin to phagocytose sperm in the lumen (Hoffer et al.1975). In monkeys, only intraluminal destruction of sperm by macrophages has been seen.

In my studies, macrophages were not visible in all sections of efferent ducts. Some macrophages may have been destroyed by fixation; it is also possible that the sections I studied were not truly representative.

Immune Complex Formation

Spermatozoa are still manufactured after vasectomy, and accumulate in the excurrent ducts. The imprisoned spermatozoa are engulfed by macrophages, or degenerate, releasing numerous antigens. With this constant antigen source, the efferent duct epithelium allows passage of antigens from the duct into the circulation. It is possible that the stretching of the efferent ducts after vasectomy may create an even "leakier" epithelium, thus permitting a greater amount of endogenous sperm antigen into the circulation, and incurring concomitant autoimmune antibody production. These antisperm antibodies then combine with the antigens, producing immune complexes. 
complexes that are too small to lodge anywhere and consequently stay in the circulation; an excess of antibody causes the formation of large immune complexes that are disposed of by the mononuclear phagocytic system.

A proportion of antibody to antigen greater than 1 would give rise to precipitates since an excess of antibody molecules allows the formation of steric aggregates of considerable volume and these spontaneously settle out from solution (Nydegger 1979). Conversely, complexes in which the antigen molecules outnumber the antibody molecules remain mostly soluble since antibodies are saturated after fixation of two antigen molecules.

Small immune complexes formed under conditions of antigen excess are under $19 \mathrm{~S}$ in size. Such complexes tend to fix complement poorly and have a prolonged intravascular half-life. Immune complexes with densities greater than $19 S$ fix complement effectively and have a relatively short intravascular life (Wells 1978).

In the basement membranes of vasectomized monkeys there are immune complex deposits visible with the electron microscope. Nonvasectomized animals lack these deposits. Sixty percent of vasectomized animals show vividly fluorescing immune complexes in the basement membrane of the efferent ducts, and $20 \%$ of nonvasectomized monkeys exhibit this fluorescence (Alexander and Tung 1979b). These percentages of fluorescence can be explained by the fact that 
tissue-bound imnune complex formation may be a part of a naturally occurring process that is possibly exacerbated by vasectomy (personal communication with Dr. Alexander).

Some animals also exhibit large, electron-dense immune complexes as revealed by electron microscopy, but do not exhibit staining with fluorescein-conjugated antibody. For example, animal 7937 had large immune complexes in the basement membrane, many plasma cells, and numerous immune complexes packed in the interstitial collagen fibers. One would expect a great deal of immunofluorescence, but none was observed. Sometimes a large group of tubules did not fluoresce whereas adjacent tubules did. Many times electrondense immune complexes could not be found in an animal that showed positive immunofluorescence. This discrepancy may have been due to the small size of the sample fixed for electron microscopy.

Localization of Immune Complexes in the Basement Membrane

Structural similarities between $\mathrm{Clq}$, one of the three subcomponents of factor $\mathrm{C} 1$ of complement, and collagen are well documented (Eeckhout et al.1976). There is some support for the hypothesis that $\mathrm{C} 1 \mathrm{q}$ and collagen interact with immune complexes. Polystyrene particles coated with human IgG are agglutinated by human skin collagen; the reaction is specific for the Fc region of IgG and for native collagen. The deposits of immune complexes in collagenous tissues such as the basement membrane could perhaps be explained by the 
particular affinity of collagen for the Fc region of IgG or perhaps other antisperm antibodies.

The width of the basement membrane did not seem to be a direct result of the large numbers of immune complexes localized in the membrane. Basement membranes were just as thick in those areas showing no deposition.

Consequences of Immune Complex Deposition

Many diseases are known to be associated with the formation of intravascular immune complexes. These diseases are associated with significant clinical features and deposition of immune complexes, and are now collectively termed the immune complex disorder. In fact, diseases such as arteritis, glomerulonephritis, and systemic lupus erythematosus, are associated with or even caused by immune complex deposition. Atherosclerosis is thought to be exacerbated by the presence of circulating immune complexes in the rhesus macaque after vasectomy (Clarkson and Alexander 1979).

A key feature in the immune complex disorder is the formation of antigen-antibody complexes in the bloodstream and their subsequent deposition at various sites in the body. During the initial immune response, antigen excess leads to the formation of soluble antigen-antibody complexes that sometimes deposit in tissues, activate complement, and initiate an inflammatory response. 
Immune complexes bind to platelet membranes, and this binding leads to the release of stored vasoactive amines (Wells 1978). The vasoactive amines increase vascular permeability and cause small blood vessel damage, which results in the precipitation of immune complexes at the basement membrane. We found no deposits in the blood vessel basement membranes surrounding the efferent ducts in vasectomized monkeys.

Persistent or continuous administration of antigen leads to an increased deposition of immune complexes in the renal glomeruli. This may occur with exogenous antigen in experimental animals, with endogenous antigens such as nucleic acid antigens (as in systemic lupus erythematosus), and with infection due to persistent replicating viruses. The glomerulus seems to be a site susceptible to immune complex deposition; whether vasectomy has a deleterious effect in the kidney similar to that of other immune complex disorders is not known. More work can be done to correlate the presence of immune complexes in the efferent ducts with that in the kidney after vasectomy.

\section{$\underline{\text { Summary }}$}

After vasectomy, the passage of sperm antigen through the epithelium of the efferent duct probably results in immune complex deposition. Immune complexes can be visualized in the thickened basement membrane by fluorescence 
microscopy. Subsequent electron microscopic evaluation, with the appearance of electron-dense deposits in the basement membrane of the rhesus efferent ducts, substantiates these findings. Definitive indentification of these electron-dense deposits as immune complexes is possible with the specific techniques such as labeling with ferritin-conjugated antibodies (Andres et al. 1966).

Studies are in progress as to some of the effects of these immune complexes formed as a result of vasectomy. 
Figure 1. The nonciliated cells of the nonvasectomized monkey contain numerous granules (g) in the apical cytoplasm. The epithelium rests on a basement membrane (arrow) that is $800 \mathrm{~A}$ wide. Apical microvilli project into the lumen (lu) of the efferent duct.

$\left(\mathrm{KMnO}_{4}\right.$ stain)

X 6,000

Figure 2. Ciliary rootlets (cr) extend deep into the cytoplasm of the ciliated cell and come into contact with mitochondria (m). Tangential sections of cilia (c) can be seen projecting into the lumen. $\left(\mathrm{KMnO}_{4}\right.$ stain) $\quad$ X 26,000 

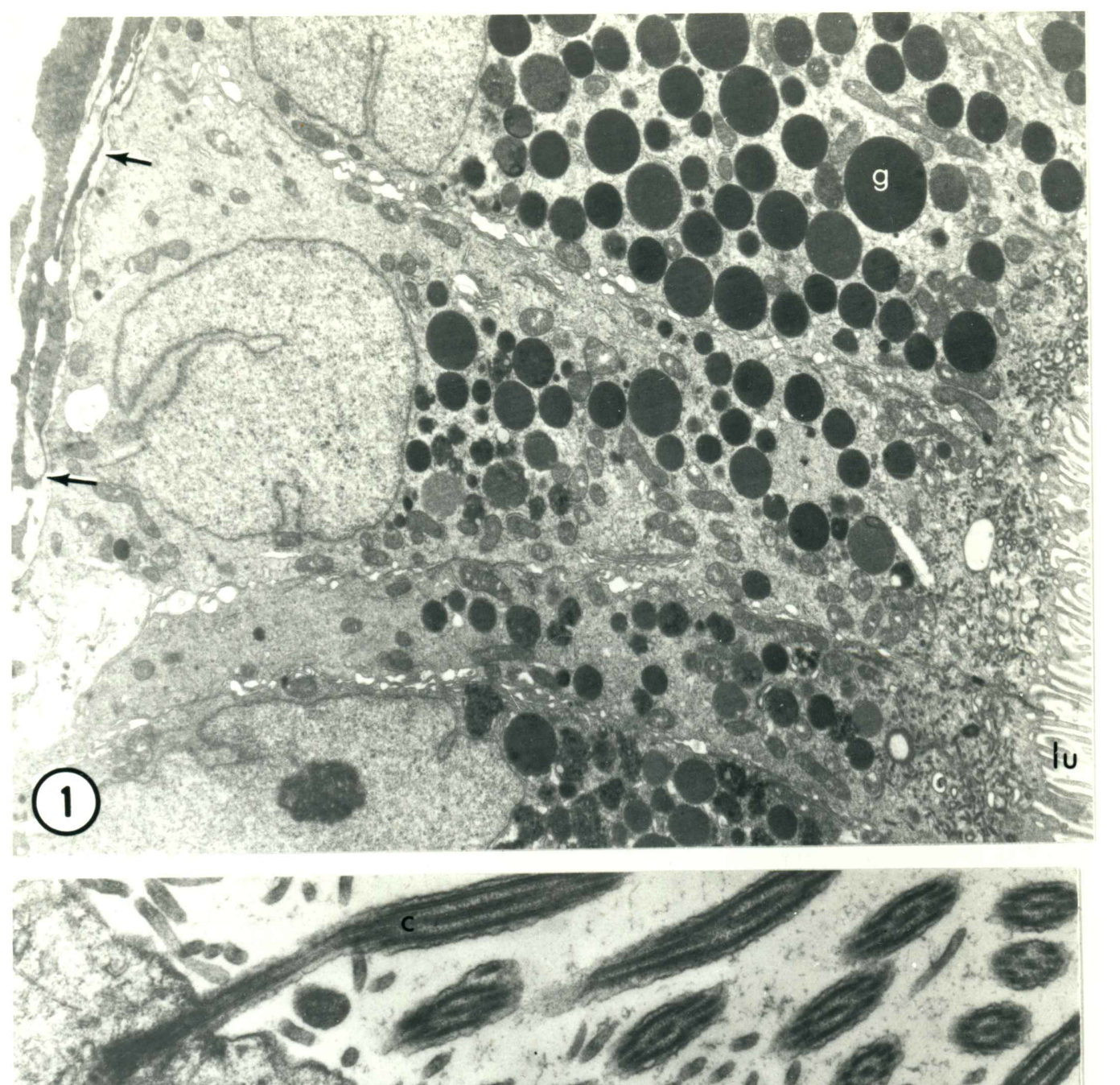

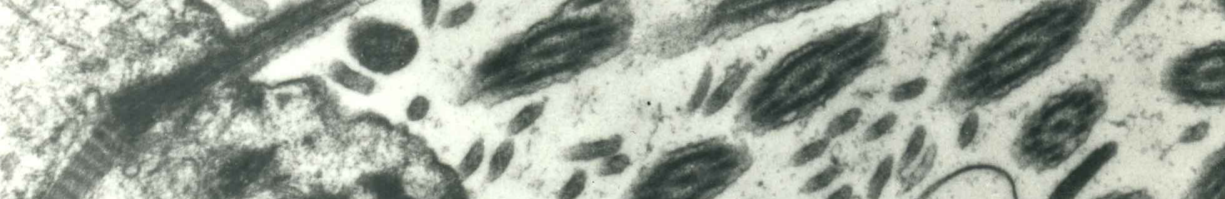

4 crs 0 . 3.l

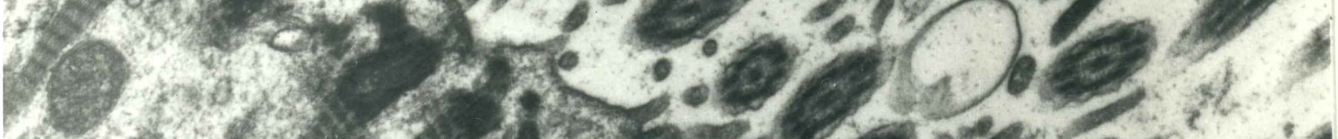

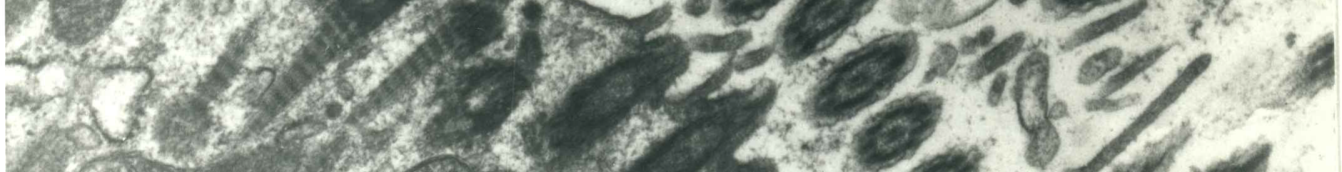

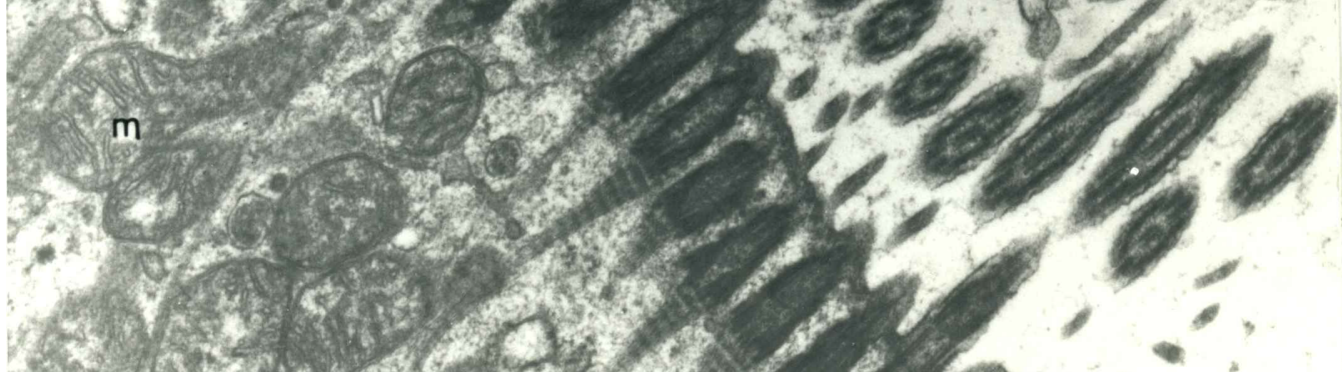
(25)

(2). $3: 2730$ 
Figure 3. Basal cells (bc) are sometimes seen in basal regions of the efferent duct epithelium. $\left(\mathrm{KMnO}_{4}\right.$ stain)

X 5,000

Figure 4. Both the ciliated cells (Cc) and nonciliated cells (NC) become shorter after vasectomy. The nonciliated cell contains many empty vesicles (v).

$\left(\mathrm{KMnO}_{4}\right.$ stain)

X 6,000 

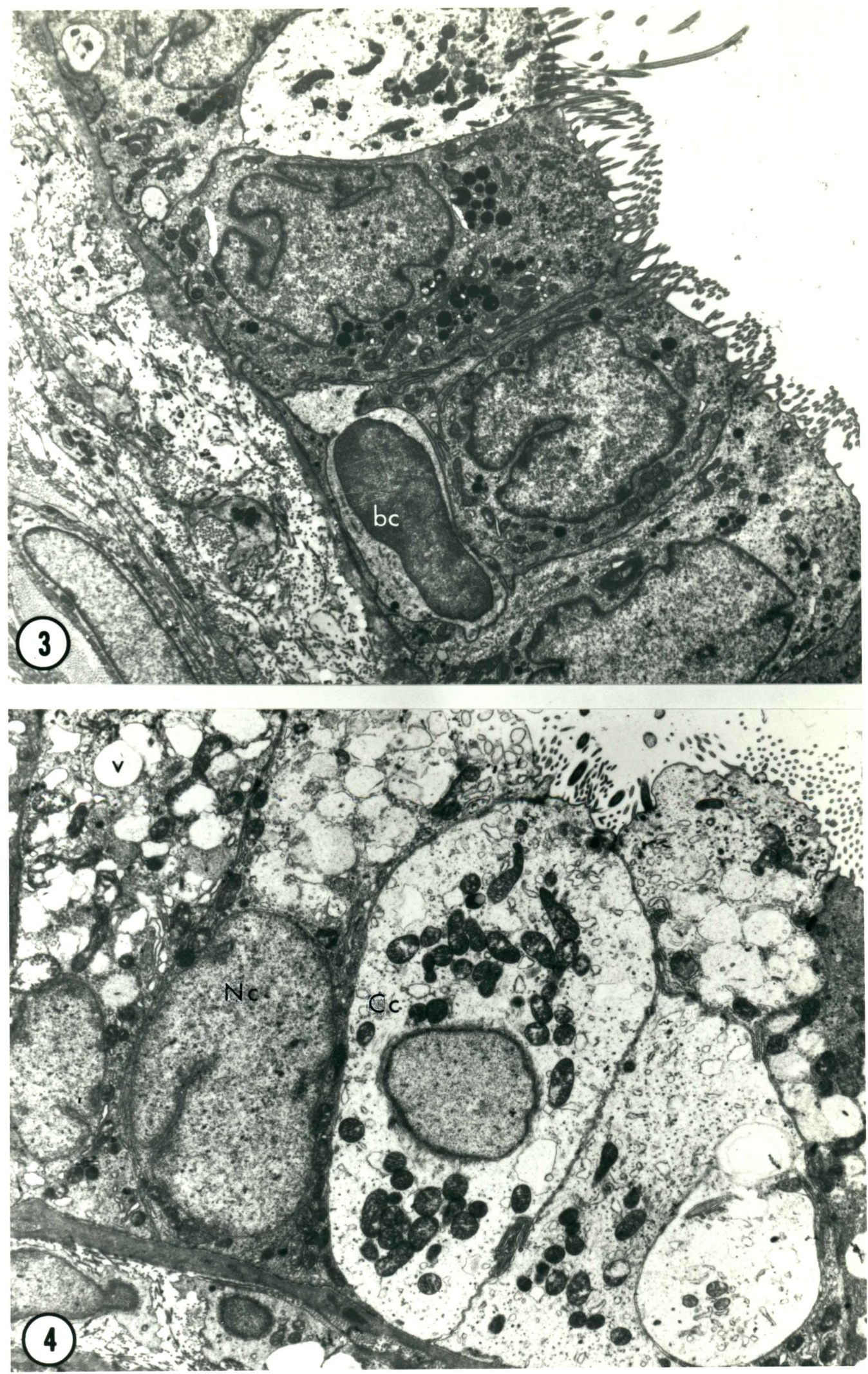
Figure 5. The number of sperm in the lumen increase after vasectomy. Sperm nuclei (sn) and cross sections through the tail (st) and midpiece (sm) are seen in this figure.

$\left(\mathrm{KMnO}_{4}\right.$ stain)

$\mathrm{X} 13,000$

Figure 6. Sperm remnants (sr) are seen within Iuminal macrophages of the efferent duct. The many surface projections and the lack of heterochromatin in the nucleus are indicative of a cell actively engaged in phagocytosis. $\left(\mathrm{KMnO}_{4}\right.$ stain)

X 8,000 


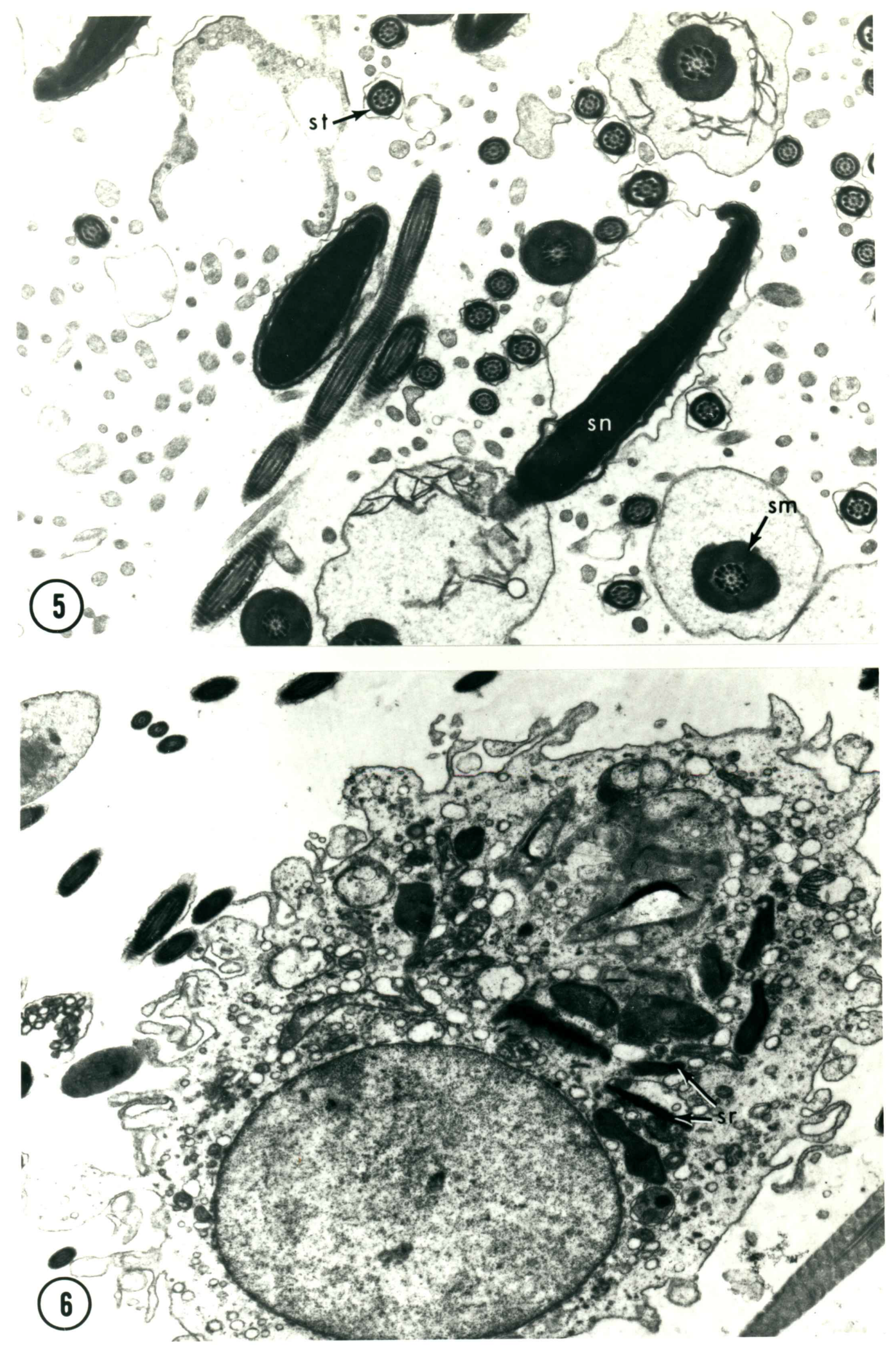


Figure 7. Within 1 year after vasectomy the basement membrane thickens by folding of many layers (arrow). $\left(\mathrm{KMnO}_{4}\right.$ stain)

$\mathrm{X} 13,000$

Figure 8. A homogeneous sheet of basement membrane (bm), sometimes up to $3 \mu \mathrm{m}$ wide, is seen in monkeys vasectomized at least 1 year earlier. $\left(\mathrm{KMnO}_{4}\right.$ stain $)$ X 11,000 


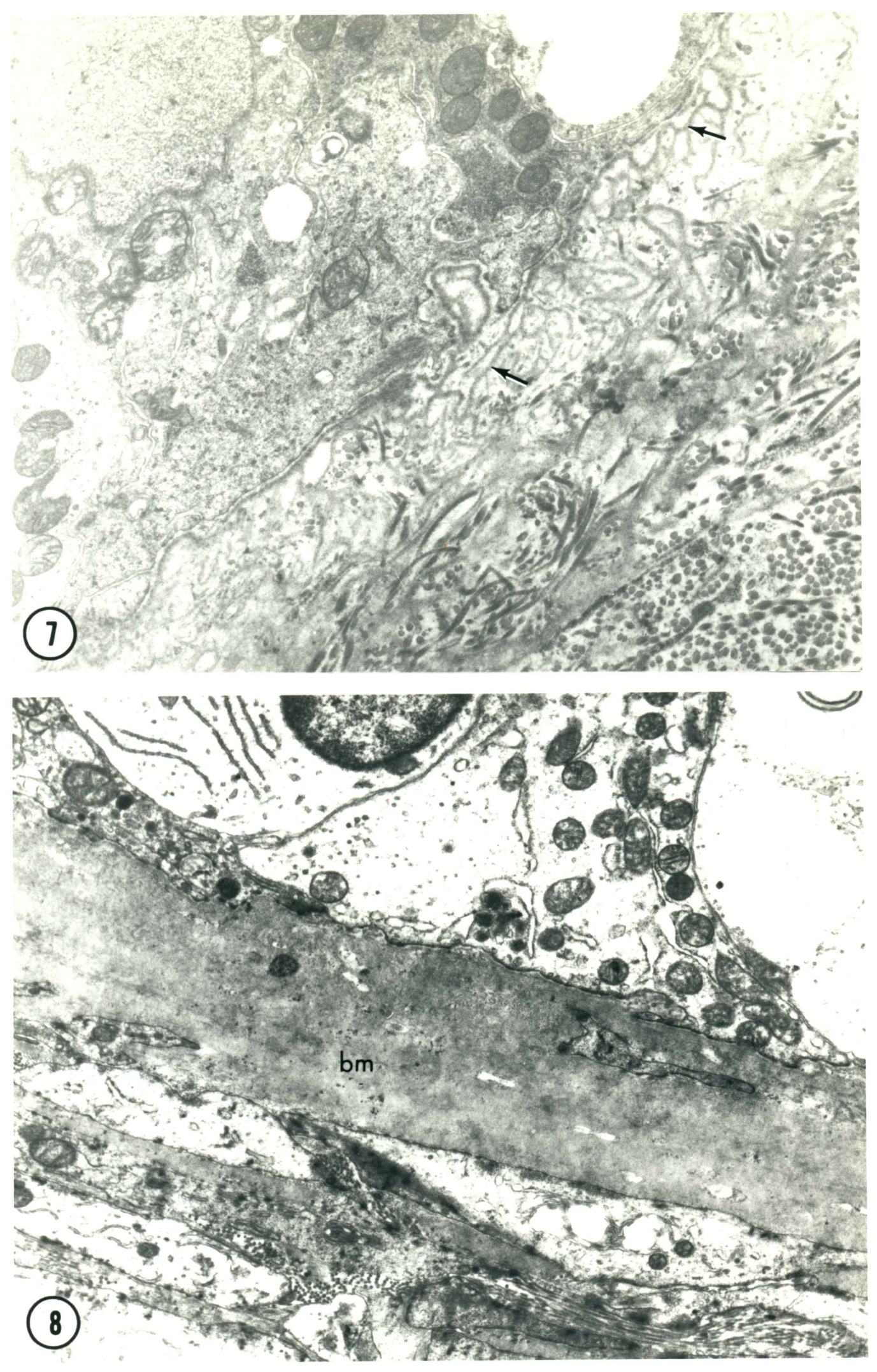


Figure 9. Invaginations (i) of the basement membrane $(\mathrm{bm})$ into the epithelium (E) are seen. Electrondense immune complex deposits (arrow) are found in the basement membrane.

$\left(\mathrm{KMnO}_{4}\right.$ stain)

X 32,000

Figure 10. The basement membrane is made up of a fibrillar component in an amorphous matrix.

$\left(\mathrm{KMnO}_{4}\right.$ stain)

X 63,000 

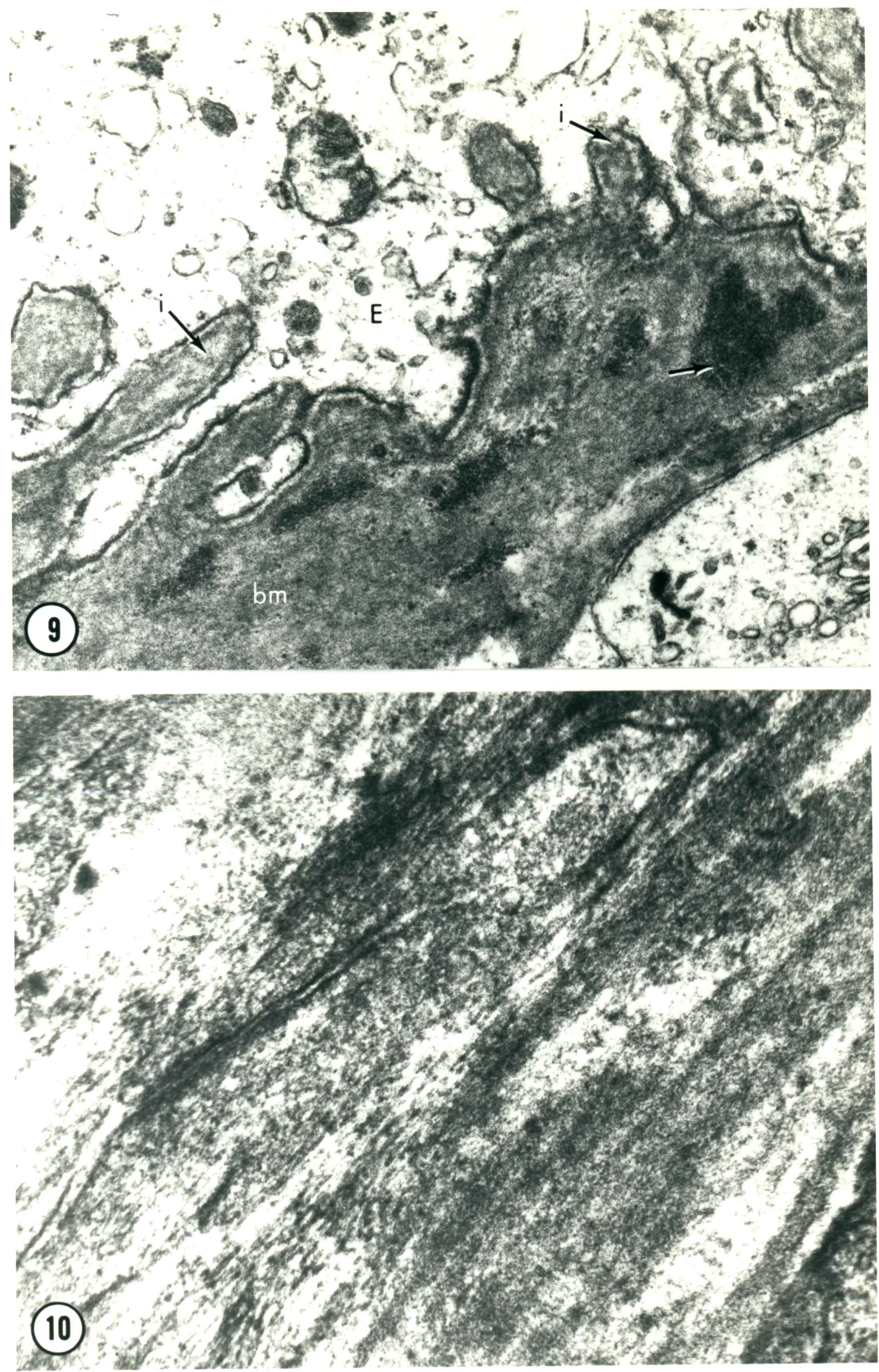
Figure 11. After vasectomy large numbers of leukocytes (le) are seen directly beneath the basement membrane (arrow). $\left(\mathrm{KMnO}_{4}\right.$ stain)

X 9,000

Figure 12. The basement membrane (arrow) surrounding the efferent duct epithelium (E) fluoresces when tested with fluorescein-conjugated antibody; this indicates the presence of immune complexes after vasectomy.

$\left(\mathrm{KMnO}_{4}\right.$ stain)

X 400 

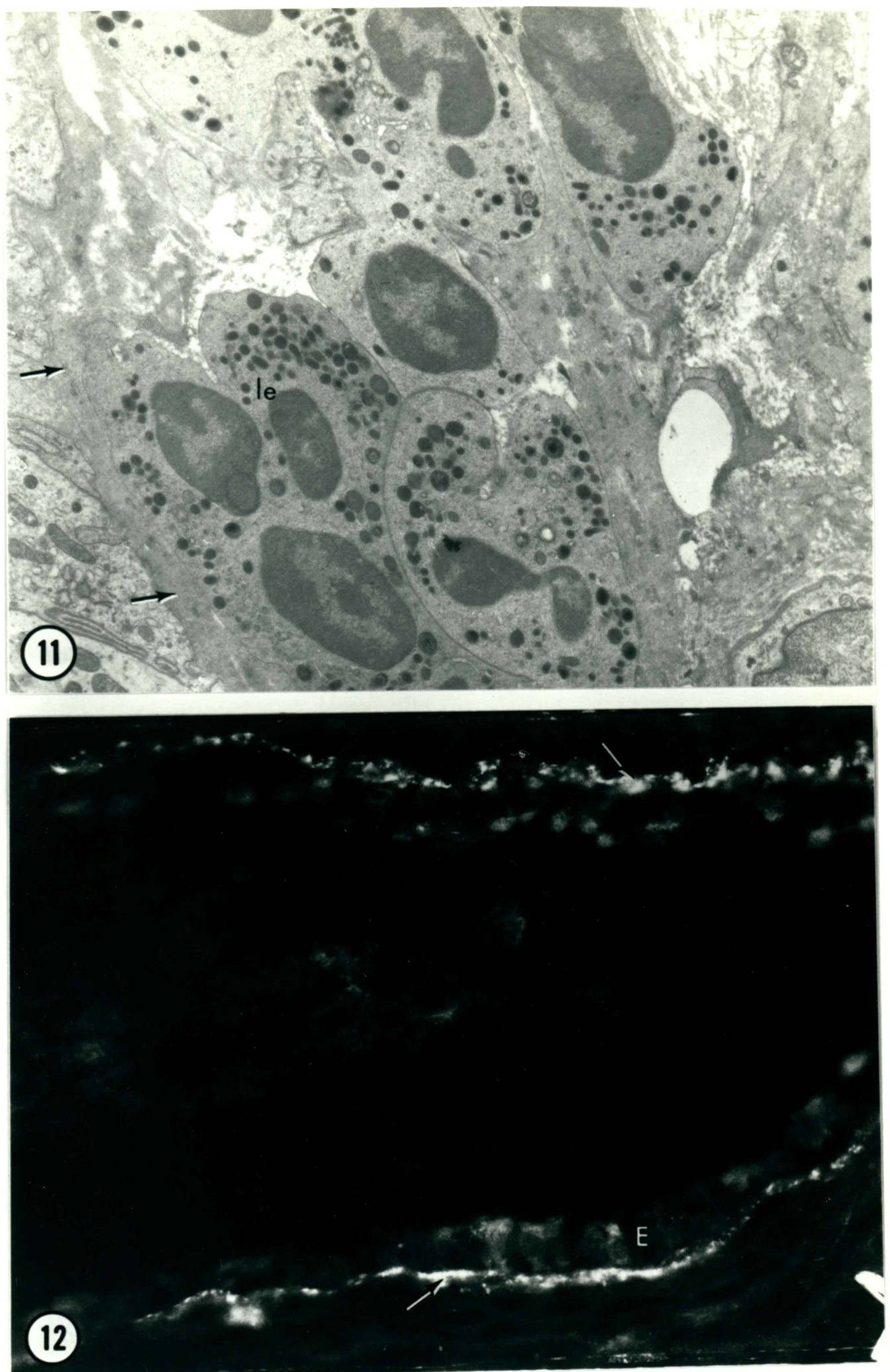
Figure 13. Electron-dense immune complexes (arrow) are seen in the basement membrane (bm) after yasectomy.

$\left(\mathrm{KMnO}_{4}\right.$ stain)

X 31,000

Figure 14. The immune complexes (arrow) appear quite different from the bundles of collagen fibers (cf) adjacent to and sometimes coursing through the basement membrane.

$\left(\mathrm{KMnO}_{4}\right.$ stain)

X 25,000 

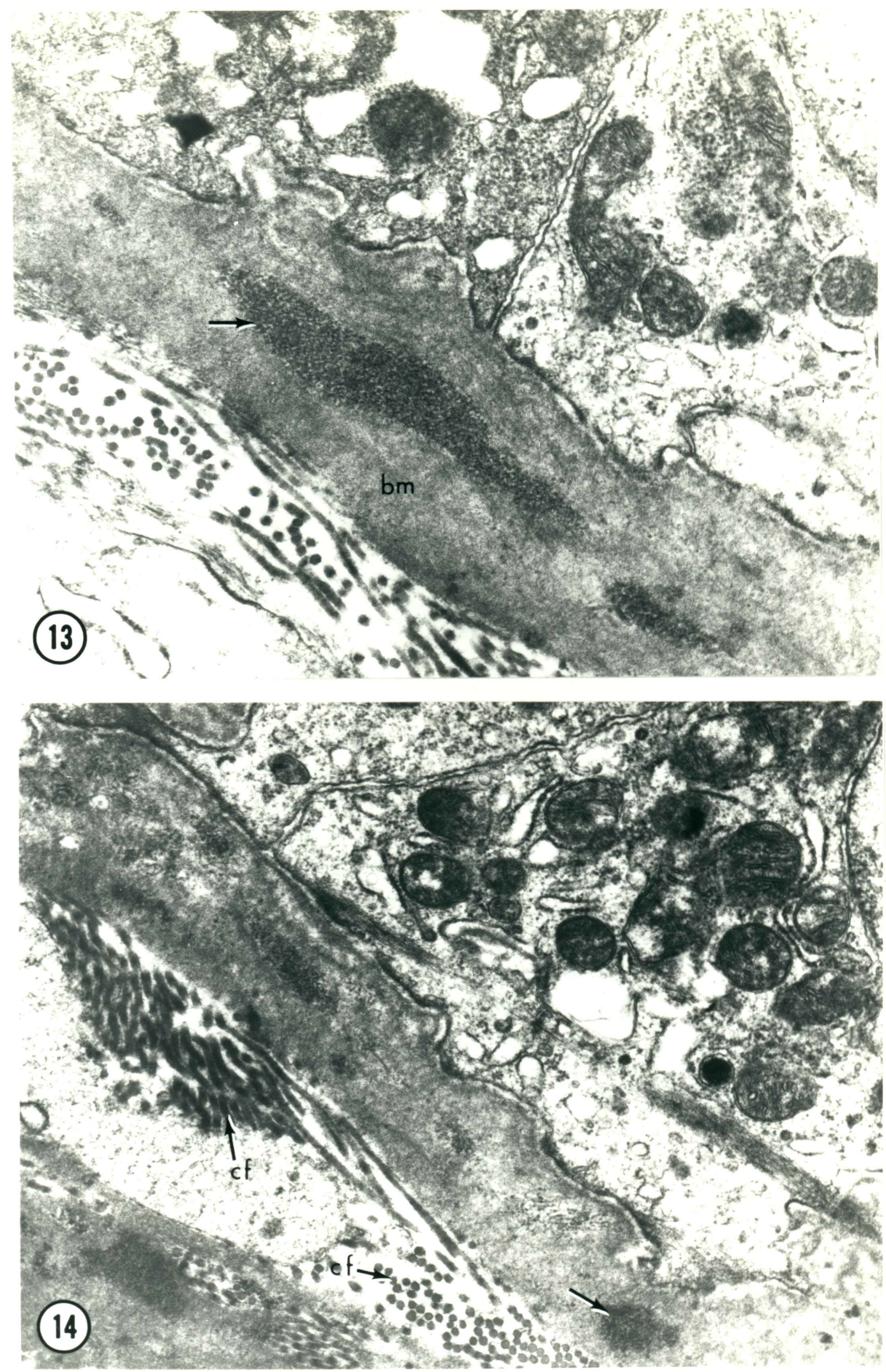
Figure 15. The immune complexes (arrow) vary in density, often appearing very dark.

$\left(\mathrm{KMnO}_{4}\right.$ stain)

X 25,000

Figure 16. Plasma cells (Pc) with a markedly developed thumbprint pattern of endoplasmic reticulum are seen directly beneath the basement membrane (bm) after vasectomy. $\left(\mathrm{KMnO}_{4}\right.$ stain)

X 11,000 
2.

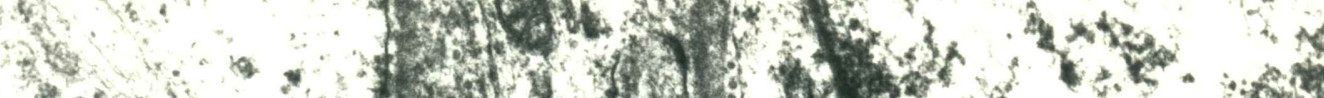

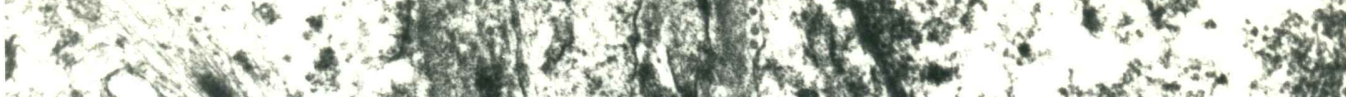

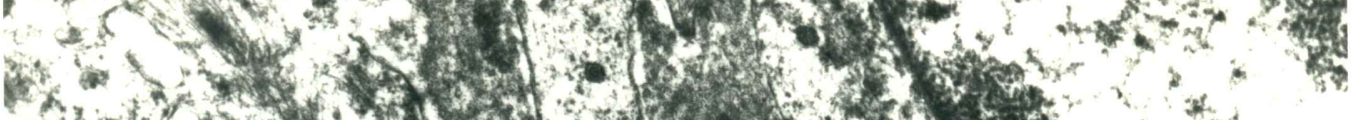
H.

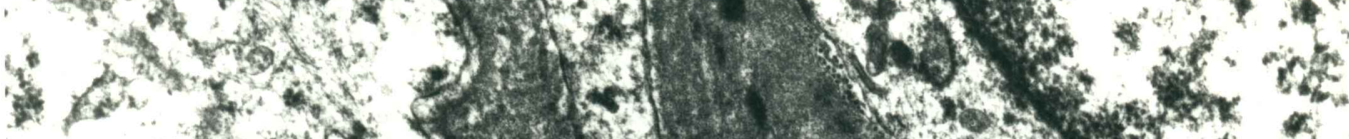

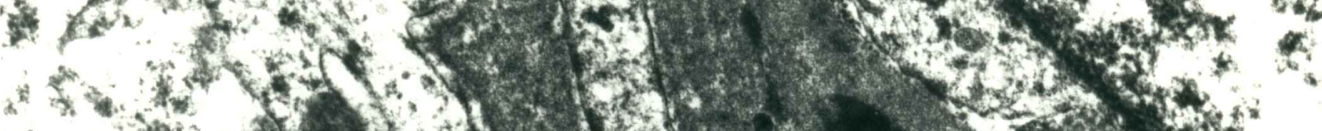

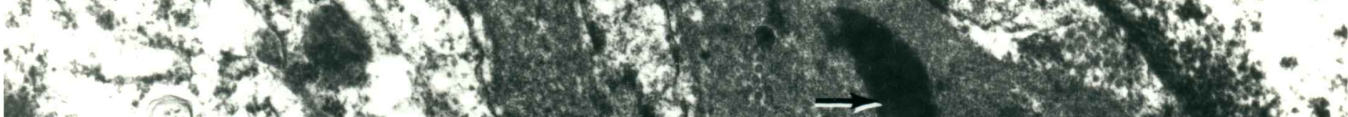

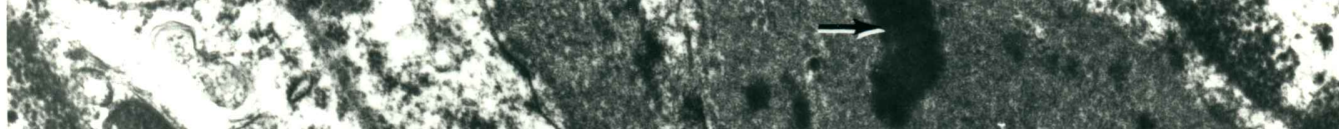

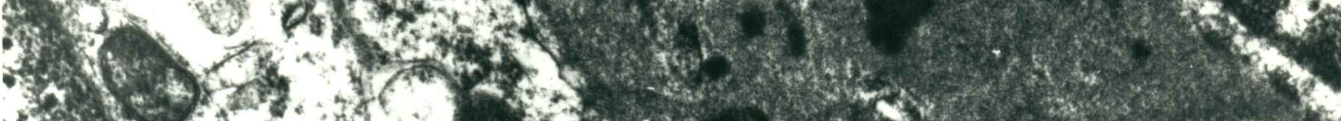

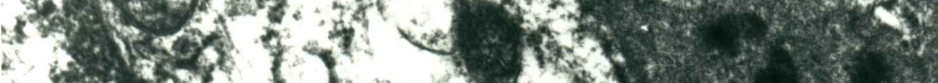

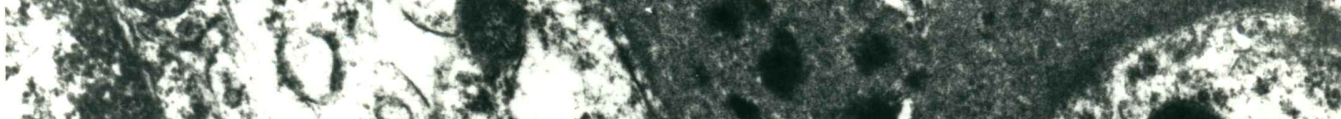

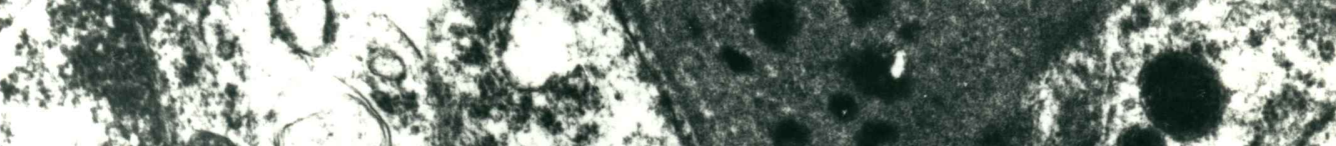

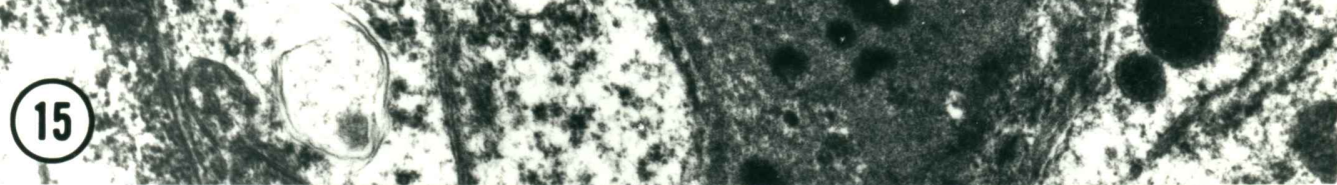

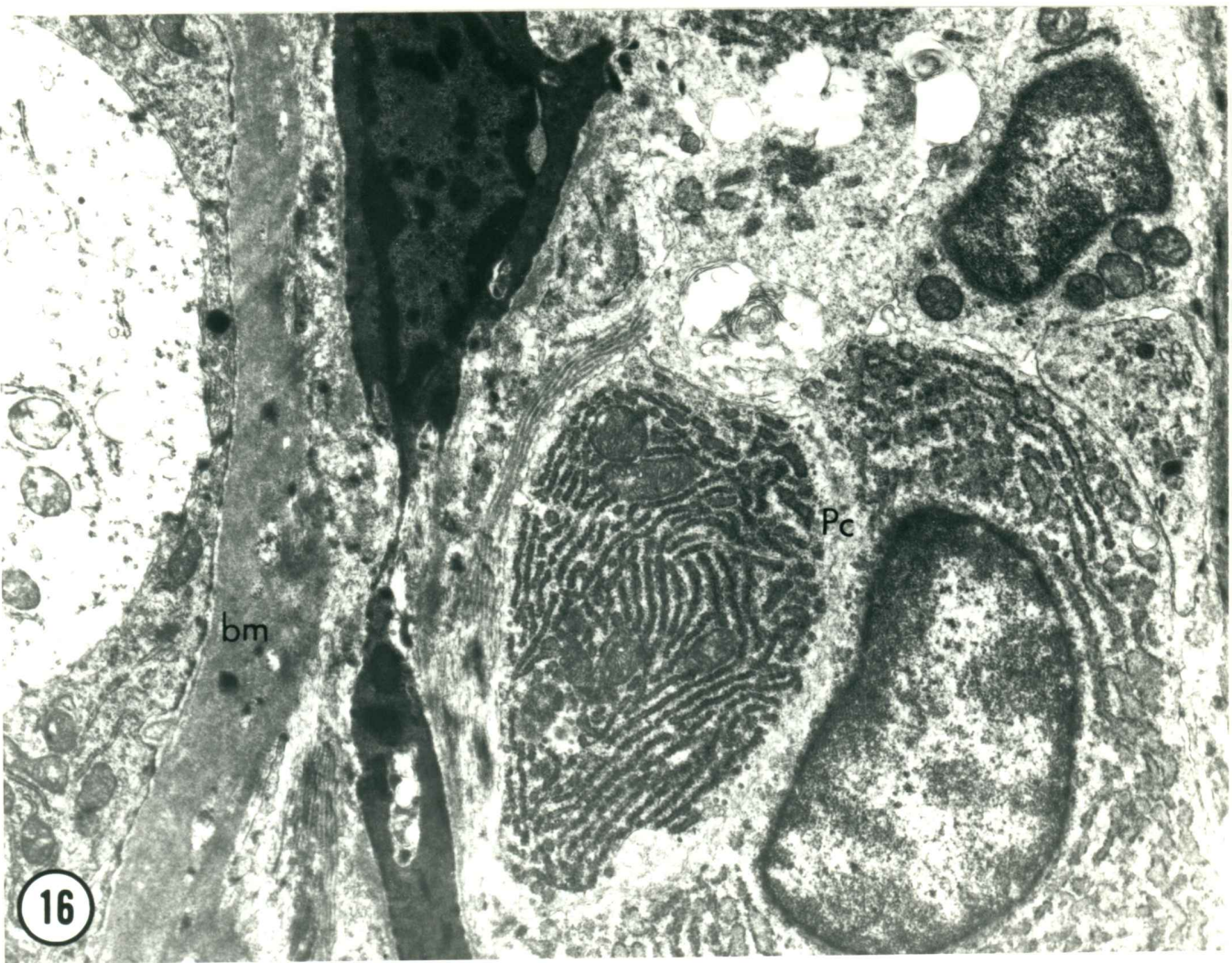


Figure 17. In 2 of 12 monkeys with immune complex deposits (arrow), plasma cells (Pc) were seen. Note the endoplasmic reticulum distended by the accumulation of antibody.

$\left(\mathrm{KMnO}_{4}\right.$ stain)

X 25,000

Figure 18. Staining sections with uranyl acetate and lead citrate makes it hard to discern the immune complexes (arrow) from the surrounding basement membrane $(\mathrm{bm})$. 


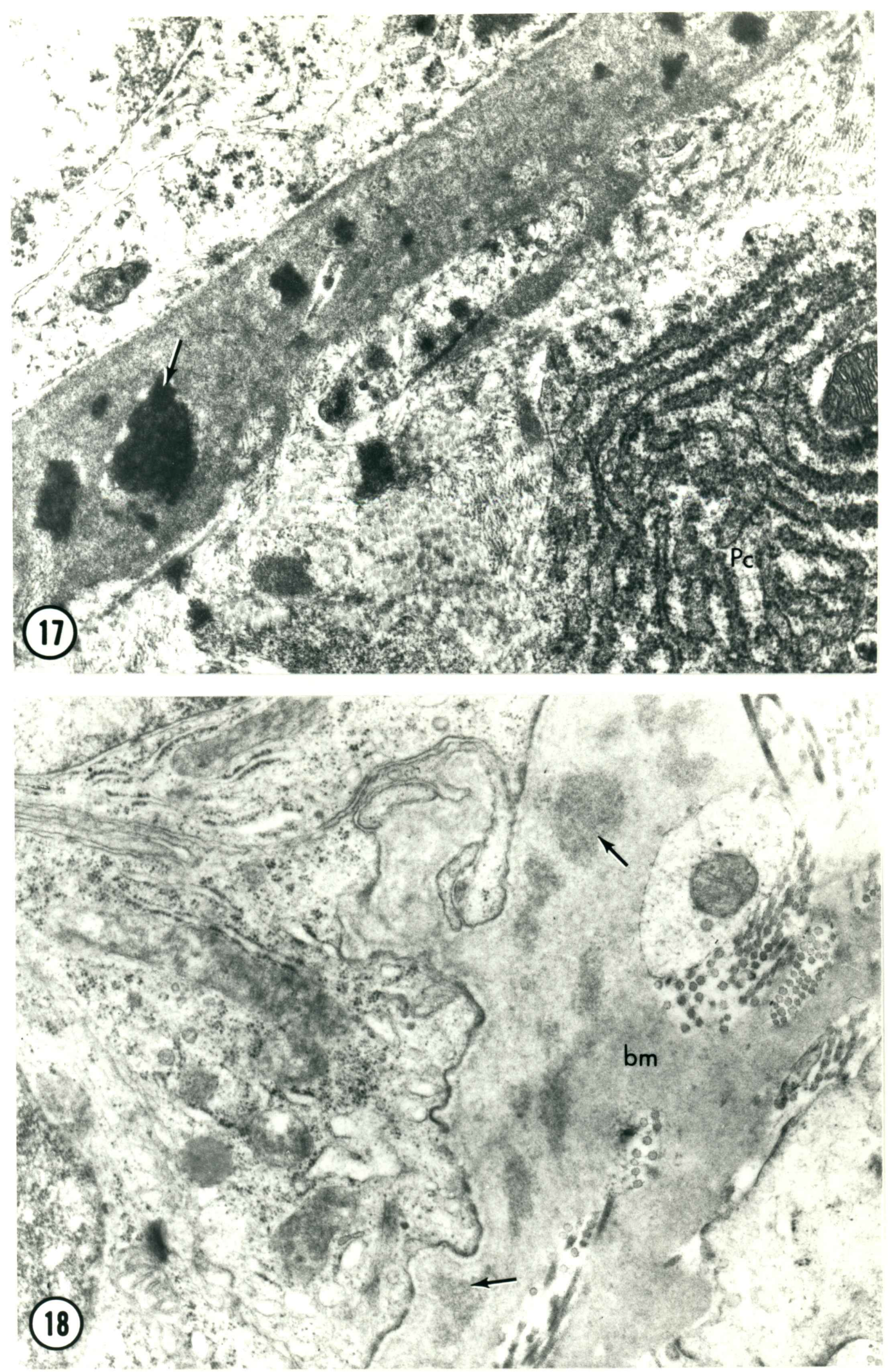




\section{LITERATURE CITED}

Alexander, N. J. (1972) Vasectomy: Long-term effects in the rhesus monkey. J. Reprod. Fert. 31, 399-406.

(1973) Ultrastructural changes in rat epididymis after vasectomy. $z$. Zeliforsch. 136, 177-182.

(1975) Immunologic and morphologic effects of vasectomy in the rhesus monkey. Federation Proceedings 34 (8), 1692-1697.

(1977) Immunological aspects of vasectomy. In: Immunological Influence on Human Fertility. (Boettcher, ed.) Acad. Press, N. Y. 25-46.

Alexander, N. J. and Clarkson, T. B. (1978) Vasectomy increases the severity of diet-induced atherosclerosis in Macaca fascicularis. Science 201, 538-541.

Alexander, N. J. and Tung, K. S. K. (1979a) Vasectomy in the rabbit: Immunological and morphological effects. In: Vasectomy: Immunologic and Pathophysiologic Effects in Animals and Man. (I. H. Lepow and R. Crozier, eds.) Acad. Press, N. Y. 355-377.

- (1979b) Effects of vasectomy in rhesus monkeys. In: Vasectomy: Immunologic and Pathophysiologic Effects in Animals and Man. (I. H. Lepow and R. Crozier, eds.) Acad. Press, N. Y. 423-458.

Andres, G. A., Accinni, L., Hsu, K. C., Zabriskie, J. B., and Seegal, B. (1966) Electron-microscopic studies of human glomerulonephritis with ferritin conjugated antibody. Localization of antigen-antibody complexes in glomerular structures of patients with acute glomerulonephritis. J. Exp. Med. 123, 399-412.

Bigazzi, P. E. (1979) Immunopathological Findings in Vasectomized Rabbits. 'In:'... 'Vasectomy: Immunologic and Pathophysiologic Effects in Animals and Man. (I. H. Lepow and R. Crozier, eds.) Acad. Press, N. Y. 339-353. 
Bigazzi, P. E., Kosuda, L. L., Hsü, K. C., and Anders, G. A. (1976) Immune complex orchitis in vasectomized rabbits. J. Exp. Med. 143, 382-403.

Briggaman, R. A., Dalldorf, F. G., and Wheeler, C. E., Jr. (1971) Formation and origin of basal lamina and anchoring fibrils in adult human skin. J. Cell Biol. $51,384-394$.

Bustos-Obregon, E. (1976) U1trastructure and function of the lamina propria of mammalian seminiferous tubules. Andrologia. 8 (3), 179-185.

Bustos-Obregon, E. and Holstein, A. F. (1973) On structural patterns of the lamina propria of human seminiferous tubule. Z. ZeZlforsch. 141, 413-425.

Chakraborty, J., Nelson, L., Jhunjhunwala, J., Young, M., and Kropp, K. (1976) Basal lamina of human seminiferous tubule--Its role in material transport. Celz Tiss. Res. 174, 261-271.

Clarkson, T. B. and Alexander, N. J. (1979) Effect of vasectomy on diet-induced atherosclerosis. In: Vasectomy: Immunlogic and Pathophysiologic Effects in Animals and Man. (I. H. Lepow and R. Crozier, eds.) Acad. Press N. Y. 121-161.

- (1980) Long-term vasectomy: Effects on the occurrence and extent of atherosclerosis in rhesus monkeys. J. Clin. INvest. 65, 15-25.

Coons, A. H., and Kaplan, M. H. (1950) Localization of antigen in tissue cells. II. Improvement in a method for the detection of antigens by means of fluorescent antibody. J. Exp. Med. 91, 1-30.

Douglas, S. D. (1978) Cells involved in immune responses. In: Basic and Clinical Immunology. (Fudenberg, H. H., Stites, D. P., Caldwell, J. L., and Wells, J. V., eds.) Lange Medical Publications, 78-95.

Eeckhout, Y., Riccomi, H., Cambiaso, C., Vaes, G., and Masson, P. L. (1976) Studies on properties common to collagen and C1q. Arch. Int. Physiol. Biol. 84, 611612 .

Fawcett, D. W. (1966) An Atlas of Fine Structure: The Cell. W. B. Saunders Co. Philadelphia and London. 
(1979) Interpretation of the sequelae of vasectomy. In: Vasectomy: Immunologic and Pathophysiologic Effects in Animals and Man. (I. H. Lepow and R. Crozier, eds.) Acad. Press N. Y. 3-23.

Flickinger, C. J., Howards, S. S., and English, H. F. (1978) Ultrastructural differences in efferent ducts and several region. of epididymis in the hamster. Amer. J. Anat. 152, (4) 557-585.

Furth, R. van, Cohn, Z. A., Hirsch, J. G., Humphrey, J. H., Spector, W. G., and Langevoort, H. L. (1972) The mononuclear phagocyte system: a new classification of macrophages, monocytes and their precursor cells. BuZZ. WZd. HZth. Org.'46, 845-852.

Hoffer, A. P., Hamilton, D. W., and Fawcett, D. W. (1975) Phagocytosis of sperm by the epithelial cells of the ductuli efferentes after epididymal obstruction in the rat. J. Reprod. Fert. 44, 1-9.

Holstein, A. F. (1978) Spermatophagy in the seminiferous tubules and excurrent ducts of the testis in rhesus monkey and in man. Andrologia. 10 (5), 331-352.

Johnson, M. H. (1970) An immunological barrier in guineapig testis. J. Path. 101, 129-139.

Ladman, A. J. and Young, W. C. (1958) An electron microscopic study of ductuli efferentes and rete testis of guinea pig. J. Biophys. and Biochem. Cytol. 4 (2), 219-226.

Marchalonis, J. J. (1978) Cell cooperation in immune responses. In: Basic and Clinical Immunology. (Fudenberg, $\overline{\mathrm{H}}$. H. et al., eds.) Lange Medical Publications, 110-122.

Nadol, J. B., Jr., and Gibbins,...T. R. (1970) Autoradiographic evidence for epithelial origin of glucose-rich components of the basement membrane (basal lamina) and basement lamella in the skin of Fundulus heteroclitus. Z. Zellforsch. 106, 398-411.

Nadol, J. B., Jr., Gibbins, J. R., and Porter, K. R. (1969) A reinterpretation of structure and development of the basement lamella: An ordered array of collagen in fish skin. Dev. Biol. 20, 304-331. 
Neaves, W. B. (1973) Permeability of sertoli cell tight junctions to lanthanum after ligation of ductus deferens and ductuli efferentes. J. Cell Biol. 59, 559-572.

- (1977) The Blood-testis barrier. In: The Testis Vol. IV.

Nydegger, U. E. (1979) Biologic properties and detection of immune complexes in animal and human pathology. Rev. Physiol. Biochem. Pharmacol. 85, 63-111.

Ramos, A. S. and Dym, M. (1977) Ultrastructure of the ductuli efferentes in monkeys. Biol. Reprod. 17, 339-349.

Suzuki, F. and Nagano, T. (1978) Regional differentiation of cell junctions in the excurrent duct epithelium of the rat testis as revealed by freeze fracture. Anat. Rec. 191, (4) 503-519.

Theofilopoulos, Argyrios N. (1980) Immune complexes in humoral immune responses: Suppressive and enchancing effects. Immunor. Today. 1 (1), 1-3.

Tung, K. S. K. and Alexander, N. J. (1980). Monocytic orchitis and aspermatogenesis in normal and vasectomized rhesus macaques (Macaca mulatta).

Vracko, R. and Benditt, E. P. (1970) Capillary basal lamina thickening. J. Cell Biol. 47, 281-285.

(1972) Basal lamina: The scaffold for orderly cell replacement. J. Cell Biol. 55, 406-419.

Wells, J. V. (1978) Immune mechanisms in tissue damage. In: Basic and Clinical Immunology. (Fudenberg, $H$. $\overline{\mathrm{H}}$. et al., eds.) Lange Medical Publications, 267282 .

Wilson, C. B., Golbus, S. M., Ward, D. M., Woodroffe, A. J., and Border, W. A. (1978) Renal Diseases. In: Basic and Clinical Immunology. (Fudenberg, H. $\bar{H}$. et al., eds.) Lange Medical Publications, 554-571.

Wing, E. J. and Remington, J. S. (1978) Delayed hypersensitivity and macrophage functions. In: Basic and Clincial Immunology. (Fudenberg, H. H. et al., eds.) Lange Medical Publications, 96-109. 
Yokoyama, M., and Chang, J. P. (1971) An ultracytochmeical and ultrastructural study of epithelial cells in ductuli efferentes of Chinese hamster. J. Histochem. Cytochem. 19, 766-774. 